\title{
ASSESSING NEW ZEALAND'S IMMIGRATION POLICY TOWARDS VICTIMS OF HUMAN TRAFFICKING: A HUMAN RIGHTS APPROACH
}

\author{
LLM RESEARCH PAPER \\ LAWS 524: HUMAN RIGHTS
}

FACULTY OF LAW

TE Whare Wánanga o te ŪPoko o te iKa a máui

2013 


\section{Abstract}

This paper assesses New Zealand's immigration policy towards victims of human trafficking, adopting a human rights approach to determining best practice. Nine principles of a human rights approach are identified. In assessing New Zealand's immigration policy, a number of gaps are identified, which result in breaches of the nine principles. To remedy these defects, two changes are recommended.

\section{Word count}

The text of this paper (excluding table of contents, footnotes, and bibliography) comprises 14,999 words.

\section{Subjects and Topics}

Human Rights

Human Trafficking

Protocol to Prevent, Suppress and Punish Trafficking in Persons, Especially Women and Children

Immigration. 
$\begin{array}{ll}\text { Introduction } & 5\end{array}$

I Background to the Assessment 6

A Trafficking in New Zealand $\quad 6$

$B$ Scope of Analysis 8

II Criteria for Assessing New Zealand's Trafficking Response 11

A The Trafficking Protocol $\quad 11$

$B$ Moving to a human rights approach $\quad 15$

1 Historic approaches to trafficking 15

2 The prosecution approach 16

3 A human rights approach 19

$C$ Eight principles for assessing New Zealand's response $\quad 21$

1 Broad definition of "victim" $\quad 21$

2 Non-criminalisation of victims 22

3 Opportunity for recovery and reflection 22

4 Victim participation in prosecutions 23

5 Protection not dependent on assisting authorities 25

6 Non-refoulement 26

7 Long-term or permanent immigration options 27

8 Provision of information and assistance 28

9 Decisions should be subject to appeal or review $\quad 29$

III Assessing New Zealand's Trafficking Response 29

A Implementation of the Protocol 30

$B$ Adequacy of trafficking response 33

1 Lack of police certification 33

2 Non-cooperation 34

3 Failed health and character requirements 35

C Asylum procedures $\quad 35$

$1 \quad$ Trafficking victims as refugees 36

2 Complementary protection $\quad 40$

3 Adequacy of asylum processes 41

D Humanitarian grounds 41

1 Humanitarian appeals $\quad 42$

2 Section 177 Discretion 44

3 Adequacy of humanitarian appeals and discretion 45

IV Recommendations $\quad \mathbf{4 5}$

$A$ The inadequacies of the current framework 45

$B$ Victim status certification 46

$C$ Amend residence visa requirements 46

$\begin{array}{lll}\text { V Conclusion } & 47\end{array}$ 
The problem of human trafficking has in the past decade captured the world's attention as an egregious and monstrous crime that threatens the dignity of nations and the security of borders. ${ }^{1}$ Trafficking in persons is now one of the world's most lucrative trades, creating millions of victims each year. ${ }^{2}$ It is now accepted that human trafficking does occur, even in New Zealand. ${ }^{3}$ In 2000 New Zealand signed the Protocol to Prevent, Suppress and Punish Trafficking in Persons, Especially Women and Children (the Protocol), which supplements the United Nations Convention Against Organised Transnational Crime, signaling its commitment to the eradication of human trafficking. ${ }^{4}$ New Zealand has also responded domestically, by updating its law and policy to ensure its consistency with the Protocol. $^{5}$

The emphasis of human trafficking discourse, as represented in the Protocol, has tended to be on the criminalization of trafficking in persons and the security concerns that it involves. ${ }^{6}$ Viewing trafficking primarily as a form of transnational crime, however, risks obscuring the human rights interests that are involved, particularly those concerning the protection of victims. While states clamour to strengthen borders and increase the sanctions for committing trafficking offences, there is a danger that victims will fall through the cracks. ${ }^{7}$ The protection of victims should be a primary concern in the world's response to human trafficking. In particular, a state's immigration policy towards victims can make or break the chances of adequate protection for victims and, therefore, should

1 See $A d$ Hoc Committee on the Elaboration of a Convention against Transnational Organized Crime Draft Protocol to Combat International Trafficking in Women and Children Supplementary to the United Nations Convention on Transnational Organized Crime GA Res 254/4 A/AC.254/4/Add.3 (1998); on trafficking generally see Anti-Slavery International $<$ http://www.antislavery.org $>$.

2 See UNESCO “Trafficking Statistics Project” (2011) < http://www.unescobkk.org $>$.

3 See Nathan Guy "Speech to the launch of STOP THE TRAFFICK Aotearoa New Zealand" (19 June 2012).

4 United Nations Convention Against Organised Transnational Crime 2237 UNTS 319 (opened for signature 15 November 2000, entered into force 25 December 2003); Protocol to Prevent, Suppress and Punish Trafficking in Persons, Especially Women and Children (the Protocol) 2225 UNTS 209 (opened for signature 15 November 2000, entered into force 29 September 2003).

5 See generally Ministry of Foreign Affairs and Trade "Protocol to Prevent, Suppress and Punish Trafficking of Persons, Especially Women and Children, Supplementing the United Nations Convention Against Transnational Organised Crime, National Interest Analysis" $<$ http://www.mfat.govt.nz $>$.

6 See for example Hon Phil Goff (Minister of Justice) Transnational Organised Crime Bill: Second Reading (30 May 2002).

7 Susan Kneebone "The Refugee-Trafficking Nexus: Making Good (The) Connections" (2010) 29 Refugee Survey Quarterly 137. 
be closely scrutinised. This paper will assess, therefore, the immigration component of New Zealand's law and policy relating to trafficking in persons.

This paper argues that New Zealand ought to adopt a human rights approach to its trafficking response. The United Nations High Commission for Human Rights (UNHCHR) explains that a human rights approach is one where states "integrate human rights into their analysis of the problem and into their responses." "This approach recognises that trafficking is not only a heinous crime; it is also a gross human rights violation. A human rights perspective prevents the problem of trafficking from being reduced to simply one of illegal migration or security of borders. In this paper, therefore, New Zealand's immigration policy towards victims will be assessed through a human rights lens.

Part I of the paper sets the stage by describing the nature of human trafficking as it relates to New Zealand. It explains why there is a need to address the problem in New Zealand, despite the low incidence trafficking cases. It then identifies the scope of the present paper and explains why it chooses to focus on the immigration component of victim protection.

In Part II the evaluative criteria used by this paper to assess New Zealand's immigration policy are explained. It starts by considering the obligations established by the Protocol, and argues that there are very few binding commitments regarding a victim's immigration status. Next, this part discusses the theoretical lens through which best practice should be considered. It is argued that the current prosecution approach, which led to the relatively weak protection standards in the Protocol, should be replaced with a human rights approach, which prioritises protecting victims. This culminates in the identification of nine principles of a human rights approach to immigration policy towards trafficking victims, which are as follows: a broad definition of a "victim"; the non-criminalisation of victims; the opportunity for recovery and reflection; the ability to participate in the criminal justice process; protection for victims independent of their willingness to assist authorities; non-refoulement; long-term residence options when return would result in further harm; information and assistance to be provided; and that decisions are subject to appeal or review.

$8 \quad$ United Nations Office of the High Commissioner for Human Rights Recommended Principles and Guidelines on Human Rights and Human Trafficking Commentary (United Nations, New York and Geneva, 2010) at 3-4. 
Part III assesses New Zealand's immigration policy towards victims of human trafficking against the nine principles articulated in Part II. It first considers the immigration policy that makes temporary and residence visas available to victims in certain circumstances. It assesses the adequacy of this programme, claiming that there are significant gaps that compromise most of the principles. The gaps relate to people who are either not certified by the police as victims, or who do not qualify for a residence visa due to health conditions or their unwillingness to cooperate with the police. ${ }^{9}$ Second, Part III explores whether asylum mechanisms provide an alternative protection mechanism for trafficking victims. It will be contended that refugee and protection status will not be available for all victims, again failing to meet the nine principles of best practice. Finally, this part considers the humanitarian grounds on which a deportation decision can be challenged. While these grounds are likely to fill many of the gaps in New Zealand's immigration policy and asylum processes, there are significant drawbacks to relying on what is a very uncertain procedure.

In Part IV, the cumulative effects of New Zealand's various immigration mechanisms are discussed in relation to the nine principles of best practice. After identifying the deficiencies in the current framework, two changes are recommended. First, victim certification should not be conducted by the police and decisions relating to certification should be subject to appeal. Second, residence visas should be extended to victims regardless of their willingness to cooperate with the police, and the health requirements should be waived for victims of human trafficking.

\section{Background to the Assessment}

\section{A Trafficking in New Zealand}

New Zealand has joined the effort to abolish trafficking through its commitment to the Protocol, but the problem of trafficking is neither straightforward nor easy to combat. Estimates of the size of the worldwide problem of people trafficking vary significantly due to the lack of conclusive and reliable data. Nevertheless, all estimated numbers are significant, indicating that the phenomenon is occurring on a momentous scale. ${ }^{10}$ The United States State Department Trafficking in Persons Report has estimated that as many

\footnotetext{
9 See Immigration New Zealand Operational Manual "Residence" (1 July 2013) $<$ http://www.immigration.govt.nz/migrant/general/generalinformation/operationalmanual/> at S4.15.5.
}

10 See for example UNESCO Trafficking Statistics Project < http://www.unescobkk.org > accessed 3 October 2013. 
as 27 million people are victims of trafficking at any one time, yet in the last year, only 40,000 victims were identified. ${ }^{11}$ One of the first struggles in suppressing the crime of trafficking in persons is to understand the size and nature of the problem, and bring a largely invisible crime into the light.

New Zealand's geographic isolation has led some to believe that it remains untouched by the scourge of trafficking in persons. ${ }^{12}$ New Zealand has, to date, conducted no prosecutions for the crime of human trafficking. ${ }^{13}$ The latest Trafficking in Persons Report issued by the United States Department of State categorised New Zealand as a Tier 1 country, meaning that it complies with minimum standards to eliminate trafficking. ${ }^{14}$

Yet this does not mean that trafficking is not occurring, or is not a possibility, in New Zealand. In 2005, United Nations Special Rapporteur on Human Trafficking, Sigma Huda, asserted that the trafficking problem in New Zealand is likely to be much broader than many believe. ${ }^{15}$ More recently, Immigration Minister Michael Woodhouse has, while asserting that the incidence of trafficking in New Zealand is low, recognised the need to avoid complacency. ${ }^{16}$ As well, the Trafficking in Persons Report issued in June this year identified New Zealand as a destination country for the trafficking of persons for forced labour. ${ }^{17}$

In a speech earlier this year, Peter Elms, the National Manager for Fraud and Operations for Immigration New Zealand highlighted some of the trafficking and exploitation scenarios that have taken place in New Zealand. ${ }^{18}$ In a recent and well-publicised incident, there were allegations of mistreatment on Foreign Charter Vessels leading to

11 United States of America Department of State "Trafficking in Persons Report" (June 2013) US Department of State $<$ www.state.gov $>$ at 2.

12 Neil Bickle, Department of Labour "Media Release 26 October 2010" < www.dol.govt.nz>.

13 Letter from B Perry (Detective Inspector, Acting National Manager New Zealand Police National Criminal Investigations Group) in response to request for information (23 September 2013).

14 United States of America Department of State "Trafficking in Persons Report", above n 11, at 279.

15 Julie Middleton "UN expert warns NZ over human trafficking problem" New Zealand Herald (21 December 2005).

16 Michael Woodhouse "Opening address to the Prevent People Trafficking Conference" (11 April 2013).

17 United States of America Department of State "Trafficking in Persons Report", above n 11, at 279.

18 Chris Frazer "Prevent People Trafficking Conference Report" (Wellington, 2013) at 7. 
changes in New Zealand's fisheries law. ${ }^{19}$ This is not an isolated occurrence. In January 2013 charges were laid against a horticulture contractor relating to the employment conditions and underpayment of illegal workers. ${ }^{20}$ Moreover the range of circumstances in which trafficking might occur is broad, including mail-order brides, foreign fishermen and arranged marriages. ${ }^{21}$

The following scenario provides a useful illustration of how trafficking can occur in New Zealand. In her 2006 report, academic Susan Coppedge describes a case of trafficking that occurred in New Zealand in 2001. ${ }^{22}$ A woman, who reported the incident to Immigration New Zealand, had been recruited with a group of Thai women to work in a restaurant in Auckland. They each agreed to repay $\$ 10,000$ plus interest at 36 percent for the job. When the women arrived in New Zealand, however, their passports and tickets were taken from them. They were then taken to their accommodation, where they slept six to a room, and $\$ 150$ per week in rent was added to their debt. Each day the women were taken to work at a brothel, with all of their earnings being taken to repay their debt. No charges were ever laid because the women were under no physical constraints and were considered free to leave. ${ }^{23}$ The case did take place before the Crimes Act was amended in 2002 to introduce an offence of human trafficking, ${ }^{24}$ but, it nevertheless demonstrates how trafficking has occurred here and serves as a useful reminder of the exploitation that can and does take place, even in remote New Zealand.

\section{B Scope of Analysis}

A comprehensive response to human trafficking requires the introduction of measures to prosecute trafficking offences, provide protection to the victims of trafficking, and prevent future trafficking from taking place. Each of these elements is crucial to the design of a complete trafficking policy, and all are covered by the Protocol. ${ }^{25}$ As a number of commentators have noted, the dialogue on transnational crime has recently focused on the crime element of trafficking, which can obscure the interests of victims

\footnotetext{
19 See Christina Stringer, Glenn Simmons and Daren Coulston "Not in New Zealand's Waters, Surely? Labour and Human Rights Abuses Aboard Foreign Fishing Vessels" (2011) 11 New Zealand Asia Institute Working Paper Series 1.

20 “Contractor exploited migrant workers" Nelson Mail (online ed, Nelson, 31 January 2013).

21 Julie Middleton, above $\mathrm{n} 15$.

22 Susan Coppedge "People Trafficking: An International Crisis Fought at the Local Level" (prepared for the Ian Axford (New Zealand) Fellowships in Public Policy, July 2006) at 60.

23 at 61.

24 Coppedge argues that this would have constituted an offence under the Act as amended.

25 Above $\mathrm{n} 4$.
} 
and compromise their rights. ${ }^{26}$ While a human rights approach can and should be applied to each element of a trafficking response, the protection stage provides the greatest opportunity to ensure that victims' rights are being upheld. This paper focuses on the adequacy of New Zealand's immigration law and policy relating to trafficking victims as one component of its protection obligations, which is significant because there is a high chance that trafficking victims will have illegal immigration status due to breaches of visa conditions and time limits. ${ }^{27}$ There are a number of reasons for this emphasis, which all arise from the central point that New Zealand's immigration policy will determine whether or not a victim is entitled to remain here or must return to his or her country of origin.

First, where immigration policy prevents a victim staying in New Zealand, there is a danger that a victim will be re-victimised when returned to his or her country of origin. ${ }^{28}$ Re-victimisation can occur to different degrees. At the less serious end, victims may be severely stigmatised, isolated from their families and deprived economically. More gravely, there is a risk that victims will suffer retribution at the hands of their traffickers. Victims may also be prosecuted by their home state for immigration-related offences committed in the course of being trafficked.

At the most extreme end there is a danger that a victim will return home, only to be trafficked once again. The International Organisation for Migration (IOM) reported in 2010 on the causes of repeated trafficking of victims. ${ }^{29}$ A combination of intersecting socioeconomic conditions make a person vulnerable to trafficking, and many of these factors are present in the case of trafficking victims. Upon return to their country of origin, victims may face difficulties finding employment or receiving education or training, making them vulnerable to re-trafficking. Victims might also remain in debt to

$26 \quad$ See for example Sharon Pickering “Transnational Crime and Refugee Protection” (2007) 34 Social Justice 47 at 47.

27 United Nations Office of the High Commissioner for Human Rights, above n 8, at 154.

28 See Kalen Fredette "Revisiting the UN Protocol on Human Trafficking: Striking Balances for more Effective Legislation" (2009) 27 Cardozo J Int'l \& Comp L 101 at 132-133; Andreas Schloenhardt and Mark Loong "Return and Reintegration of Human Trafficking Victims from Australia” (2011) 27 Int J Refugee L 143 at 154; and Training Manual for Combating trafficking in Women and Children, developed as part of the United Nations Inter-agency Project on Trafficking in Women and Children in the Sub-Mekong Region $<$ http://www.un.or.th/traffickingProject/trafficking_manual.pdf $>$.

29 International Organisation for Migration "Consequences of Re-trafficking: Evidence from the IOM Human Trafficking Database” (2010). 
those involved in their original exploitation, making it difficult to escape further exploitation. The stigma that accompanies a victim's trafficking experience may cause rejection among family or community members and result in a lack of protection from future trafficking. ${ }^{30}$ The IOM found that young people in particular are vulnerable to retrafficking and that the danger of re-trafficking is high immediately after a victim exits a trafficking situation. ${ }^{31}$ These risks that a victim may face if returned to his or her home country illustrate that New Zealand's immigration policy is an important element of protection or lack thereof.

Second, protecting victims necessarily depends on their recognition as trafficking victims, and immigration policy can influence whether this identification takes place. Identifying victims is inherently difficult for a number of reasons. Trafficking victims have been described as "invisible" from detection, which is the result of various, complex dynamics. ${ }^{32}$ Victims may feel emotionally tied to their traffickers, be embarrassed about their situation, or feel afraid of their traffickers. ${ }^{33}$ As well, academics have noted that victims often fear the consequences of cooperation with police, particularly if they are concerned about being liable for their complicity in offending. ${ }^{34}$ If New Zealand's immigration policy were to give rise to a fear amongst victims of deportation, this could only be expected to inhibit identification of victims further. On the other hand, to provide victims with certainty of immigration protection could be expected to reduce the barriers to them coming forward. New Zealand's immigration policy can influence whether a victim will feel safe approaching law enforcement authorities or otherwise seeking help and, accordingly, it can either contribute towards or detract from, the identification of victims.

This challenge of identifying victims can, in part, be improved through a greater focus on education and awareness training for officials in front-line agencies. Part of New Zealand's response to people trafficking is built on raising awareness. ${ }^{35}$ The police have implemented a new training module on people trafficking crimes and the Department of Labour has started training compliance staff $\square$ on indicators of people trafficking before each operation in the sex industry or wherever else there is a possibility of exposure to

\footnotetext{
$30 \quad$ at 13.

31 at 12 .

32 Susan Kneebone, above n 7, at 138.

33 at 37.

34 Susan Coppedge, above n 22, at 37; Susan Kneebone, above n 7, at 148.

35 Department of Labour "Plan of Action to Prevent People Trafficking" (2009) <www.dol.govt.nz> at 8 .
} 
trafficking activity. Health and Safety officers and Labour Inspectors are to be trained on how to detect trafficking in the course of their inspections. The difficulties in identifying victims run deep though, and cannot be solved without addressing the incentives and disincentives created by New Zealand's immigration policy.

Third, further protective mechanisms cannot be extended to a victim who is unable to remain in New Zealand due to illegal immigration status. New Zealand's policy response to trafficking includes the provision of housing and other social services to victims, which are important elements of assisting their recovery. ${ }^{36}$ These services will not, however, be available in the case that a victim is deported from New Zealand.

For these reasons it is essential that a satisfactory immigration policy forms part of the victim protection component of New Zealand's trafficking response. While any response to trafficking in persons must be comprehensive and deal with the prevention and prosecution of trafficking, this paper explores only the protection element of the response. Although there are many agencies and programmes that can form part of the victim protection element, this paper focuses on New Zealand's immigration policy, which is an essential element of protection and a prerequisite for further protection in many cases.

\section{Criteria for Assessing New Zealand's Trafficking Response}

This part will establish the criteria against which New Zealand's trafficking response is to be assessed. It begins by setting out New Zealand's obligations under the Protocol. Second, it describes what is meant by a human rights approach to trafficking and explains why such an approach is more appropriate than the prosecution approach that the Protocol embodies. Finally, it elucidates nine principles of a human rights approach to the protection of trafficking victims through immigration policy.

\section{A The Trafficking Protocol}

New Zealand is party to the Protocol, which entered into force in December 2003. The Protocol is not the first international instrument concluded for the purpose of combatting trafficking in persons, a testimony to the fact that trafficking is not a modern phenomenon. The Protocol does however reflect renewed energy amongst the international community to combat trafficking as a form of organised crime. Arguably, it provides the most comprehensive framework to date. ${ }^{37}$ Of particular significance is the

36 Department of Labour "Plan of Action to Prevent People Trafficking", above n 35, at 18-20.

37 Kalen Fredette, above n 28, at 112. 
development of an agreed definition of trafficking. The Protocol defines "trafficking in persons" as: ${ }^{38}$

... the recruitment, transportation, transfer, harbouring or receipt of persons, by means of the threat or use of force or other forms of coercion, of abduction, of fraud, of deception, of the abuse of power or of a position of vulnerability or of the giving or receiving of payments or benefits to achieve the consent of a person having control over another person, for the purpose of exploitation. Exploitation shall include, at a minimum, the exploitation of the prostitution of others or other forms of sexual exploitation, forced labour or services, slavery or practices similar to slavery, servitude or the removal of organs.

Trafficking is commonly said to include three elements: ${ }^{39}$ (a) the action of recruitment, transportation, transfer, harbouring or receipt of persons; (b) by means of the threat or use of force or other forms of coercion; and (c) for the purpose of exploitation.

Another advantage of the Trafficking Protocol is its multi-faceted approach towards the problem. The Trafficking Protocol's purposes are threefold: ${ }^{40}$

(a) To prevent and combat trafficking in persons, paying particular attention to women and children;

(b) To protect and assist the victims of such trafficking, with full respect for their human rights; and

(c) To promote cooperation among States Parties in order to meet those objectives.

The Legislative Guidelines to the Protocol remind us that the Convention against Transnational Organised Crime and its Protocols are primarily criminal justice instruments. ${ }^{41}$ For example, The Protocol requires States parties to adopt legislation that criminalises trafficking according to the above definition. ${ }^{42}$ But, as the tripartite purposes

$38 \quad$ Above $n$ 4, art 3(a).

39 United Nations Office on Drugs and Crime Division for Treaty Affairs Legislative Guides for the Implementation of the United Nations Convention Against Transnational Organized Crime $\square$ and The Protocols Thereto (Legislative Guides) (United Nations, New York, 2004) at 268. United Nations Protocol to Prevent, Suppress and Punish Trafficking in Persons, Especially Women and Children 2237 UNTS 319 (Signed 15 November 2000, entered into force 25 December 2003) art 2.

41 United Nations Office on Drugs and Crime Division for Treaty Affairs Legislative Guides, above n 39, at 286.

42 art 5(1). 
indicate, the scope of the Protocol is broader than criminalisation, such as measures to prevent further trafficking and encourage the exchange of information. As well, although the Protocol is not a human rights instrument, it does create a number of obligations for the protection of victims. Articles 6 to 8 of the Protocol set out these obligations, and therefore provide the basis of New Zealand's protection commitments towards trafficking victims.

Article 6 sets out the various obligations of states in relation to the assisting and protecting victims. It establishes that States parties, in appropriate cases, must protect victims' privacy, ensure their access to legal proceedings and ensure victims are able to obtain compensation for the harm they have suffered. ${ }^{43}$ Paragraph 2(b) mirrors art 25(3) of the Convention Against Transnational Organised Crime, which requires States parties to assist victims' participation in criminal proceedings against offenders. ${ }^{44}$ The Legislative Guidelines to the Protocol suggest this may mean that receiving states (that is, states to which a person is trafficked) should defer removing victims until after they have had this opportunity. ${ }^{45}$ Article 6(3) also requires that States parties provide for the recovery of victims including, in appropriate cases: the provision of housing; counselling and information about their legal rights; medical, psychological and material assistance; and employment, education and training opportunities. ${ }^{46}$ Furthermore, art 6(5) obliges States to "endeavour to provide for the physical safety of victims of trafficking in persons while they are within its territory."

The strength of states' obligations under art 6 is weakened by the language adopted in the Protocol. The repeated use of the phrase "in appropriate cases" to define the extent of states' obligations indicates that decisions relating to the protection of victims are under the discretion of States parties. During negotiations concerning the Protocol, some groups argued that the phrase "in appropriate cases" should be removed from the provisions in art 6 to strengthen the obligations contained therein. ${ }^{47}$ The phrase was, however, left in.

Article 7 of the Protocol deals directly with the immigration component of protection and

\footnotetext{
43 Trafficking Protocol, above $\mathrm{n}$ 4, arts 6(1), 6(2) and 6(6).

44 Above $\mathrm{n} 4$.

45 United Nations Office on Drugs and Crime Division for Treaty Affairs Legislative Guides, above n 39, at 287.

46 Above n 4, art 6(3).

47 see the United Nations High Commissioner for Human Rights Informal Note: Ad Hoc Committee on the Elaboration of a Convention Against Transnational Organized Crime GA Res 254 A/AC.254/16 (1999) at [19].
} 
obliges States parties to "consider adopting legislative or other appropriate measures that permit victims of trafficking in persons to remain in its territory, temporarily or permanently, in appropriate cases," giving appropriate consideration to humanitarian and compassionate factors. The preparatory works indicate that "humanitarian" factors, which should be considered in every case, are the rights contained in human rights instruments. "Compassionate factors" are the personal circumstances of the victim such as family situation, age, and relationship, which should be considered on a case-by-case basis. ${ }^{48}$

There was considerable debate during the drafting of the Protocol about what the appropriate status of trafficking victims should be. ${ }^{49}$ Some delegations proposed the deletion of the words "in appropriate cases" from art 7, while others proposed that these words should be used to qualify only permanent residence. ${ }^{50}$ Developed countries, which tend to be receiving states in the trafficking exchange, generally opposed the inclusion of a legal right to remain during negotiations, fearing that such a right would incentivise trafficking and illegal immigration. ${ }^{51}$ The United Nations High Commission for Human Rights (UNHCHR) went so far as to submit by way of an informal note that the identification of a person as a trafficking victim should be sufficient to ensure that he or she does not face expulsion. ${ }^{52}$ However, the delegations ultimately acknowledged that the paragraph was not intended to confer on a victim the right to remain. One commentator writes that including such a right was never a serious option. ${ }^{53}$ The final form of art 7 has been criticised by members of the NGO community for being non-binding and too ambiguous. It clearly leaves it to the discretion of a State party whether or not to grant temporary or permanent residence. ${ }^{54}$

Finally, art 8 requires both receiving states and states where a victim is a national or permanent resident to facilitate the safe return of victims. ${ }^{55}$ Yet the obligations on receiving states are very limited. Under art 8(2), repatriation shall be undertaken with due

$48 \quad$ at 380.

49 United Nations Office on Drugs and Crime Travaux Préparatories of the Negotiations for the Elaboration of the United Nations Convention Against Organized Transnational Crime and the Protocols Thereto (Travaux Préparatories) (United Nations, New York, 2006) at 378-380. at 380 .

51 Elizabeth Defeis "Protocol to Prevent, Suppress and Punish Trafficking in Persons - A New Approach" (2004) 10 ILSA J INT'L \& COMP L 485 at 489.

52 at 379.

53 Anne Gallagher "Human Rights and the New UN Protocols on Trafficking and Migrant Smuggling: A Preliminary Analysis" (2001) 23 Hum Rts Q 975 at 992.

54 United Nations Office on Drugs and Crime Travaux Préparatoires, above n 49, at 380.

55 Trafficking Protocol, above n 4, arts 8(1) and 8(2). 
regard for the safety of the victim, and it should preferably be on a voluntary basis. ${ }^{56}$ According to the UNHCHR, "safe and, as far as possible, voluntary return must be at the core of any credible protection strategy for trafficked persons." 57 The interpretive notes on the Protocol, however, make emphatically clear that the words, "shall preferably be voluntary," do not place any obligations on receiving states. ${ }^{58}$

Therefore, New Zealand's commitment to the Protocol does not establish many binding obligations. In terms of immigration responses, the Protocol simply requires that New Zealand "consider" whether or not to provide immigration status to victims. ${ }^{59}$ This discretion is to some extent limited by the obligation to have due regard for the safety of a victim when repatriating and the obligation to facilitate victims' participation in prosecutions. ${ }^{60}$ But even so, the emphasis of the Trafficking Protocol is clearly not on standardising the protection of victims.

\section{B Moving to a human rights approach}

Over the past century, the international community has confronted trafficking in persons through a variety of instruments, each reflecting a different perspective on what the nature of trafficking is. The Protocol is simply the latest development in this saga, and it too is born out of a particular theoretical view. While the Protocol is the most comprehensive attempt to combat trafficking to date, there are significant deficiencies in its treatment of victims. This section outlines the development in internationally held attitudes to trafficking and argues that states should shift to a human rights approach, as was advocated by a number of international organisations during the drafting of the Protocol.

\section{Historic approaches to trafficking}

Human trafficking was originally conceptualised as an issue of forced prostitution. ${ }^{61}$ Consequently, 1904 and 1910 saw the conclusion of the International Agreements for the Suppression of the "White Slave Trade", which criminalised the abduction and foreign

\footnotetext{
$56 \quad$ art 8(2).

57 United Nations High Commissioner for Human Rights Informal Note, above n 47, at [20].

58 United Nations Office on Drugs and Crime Travaux Préparatoires, above n 49, at 385.

59 Trafficking Protocol, above n 4, art 7(1).

60 Art 8(2).

61 Kalen Fredette, above n 28, at 108.
} 
sale of white women for sex work. ${ }^{62}$ Two further Conventions in 1921 and 1933 expanded the scope of their application to non-white women. In 1949, the Convention for the Suppression of the Traffic in Persons and Exploitation of the Prostitution of Others consolidated previous instruments, and provided a basis for the subsequent era of law and policy. ${ }^{63}$ This initial focus on prostitution was problematic for a number of reasons, in part because it excluded other forms of labour trafficking and because it failed to distinguish between forced and consensual prostitution. It also treated rescued persons as criminals rather than victims: they often faced prosecution for immigration related offences or prostitution. ${ }^{64}$

A new perspective on trafficking, focusing on the victimhood of women, became prevalent in the 1970s, which is evident in the provisions of the Convention on the Elimination of All Forms of Discrimination Against Women (CEDAW). ${ }^{65}$ This too represented a limited perspective because it excluded men from the victim category. It was also problematic because of the distinction it drew between those who do and do not consent to elements of their trafficking, failing to recognise the former category as victims. ${ }^{66}$

\section{The prosecution approach}

The Protocol was drafted in response to the fresh proliferation of human trafficking that followed the Cold War, and the lack of a comprehensive framework to adequately combat it. ${ }^{67}$ The Protocol addresses many of the problems with previous approaches by expanding the definition of trafficking to all persons, recognising the victimhood of trafficked persons, and making consent of the victim irrelevant. ${ }^{68}$ The Protocol represents, however, a certain perspective on trafficking and has associated limitations.

\footnotetext{
$62 \quad$ International Agreement for the Suppression of the "White Slave Trade," 1 LNTS 83 (18 May 1904); International Agreement for the Suppression of the "White Slave Trade," 3 LNTS 278 (4 May 1910).

63 Convention for the Suppression of the Traffic in Persons and Exploitation of the Prostitution of Others 96 UNTS 271 (25 March 1950).

64 Kalen Fredette, above n 28, at 110.

65 Convention on the Elimination of All Forms of Discrimination Against Women 1249 UNTS 13 (opened for signature 18 December 1979, entered into force 3 September 1981).

$66 \quad$ Kalen Fredette, above n 28, at 111.

67 Elizabeth Defeis, above n 51, at 486.

68 Trafficking Protocol, above n 4, art 3(b).
} 
The scholar Dina Francesca Haynes has branded this perspective as the "prosecution model". 69

The Protocol evidently focuses on trafficking as a matter of organised crime and, because this is the primary policy concern, states have naturally emphasised the law enforcement component of trafficking. During negotiations concerning the Protocol, Member States sought to find a balance between law enforcement and victim protection, and it appears that the resulting Protocol has come down on the side of law enforcement. ${ }^{70}$ It contains strong obligations to prosecute trafficking offences, but has been critcised as a "lost opportunity" to protect the rights of trafficking victims. ${ }^{71}$ As one commentator notes, the dialogue on transnational crime, which has tended to focus on the human smuggling and crime elements of trafficking, obscures the interests of protection. ${ }^{72}$ For example, when it comes to the immigration status of victims, as explained above, the Protocol provides very little in the way of obligations for their protection. ${ }^{73}$ Moreover, the Protocol's protection clauses are better explained as a means to facilitate prosecution, rather than as an end in themselves. For example, arts 6(1) and 6(2) provide clear protections for victims who are involved in the criminal justice process, whereas the obligation in art $6(3)$ that relates to victims more generally is much weaker: it only requires States parties to "consider" implementing support measures in "appropriate cases".

This prosecution approach to trafficking has also manifested in the domestic law and policy that states have adopted in response to trafficking. For example, the Council of Europe, in its Directive on the Residence Permit Issued to Third-country Nationals who are Victims of Trafficking in Human Beings or who have been the Subject of an Action to Facilitate Illegal Immigration, who Cooperate with the Competent Authorities (Directive on the Residence Permit), made it clear that these were not for the purpose of protecting victims but were intended to facilitate prosecutions. ${ }^{74}$ The Australian policy

69 Dina Francesca Haynes "Used, Abused, Arrested and Deported: The Case for Extending Immigration Benefits to Protect Victims of Trafficking and Secure the Prosecution of Traffickers" (July 24, 2003) Bepress Legal Series Bepress Legal Series Working Paper 6 $<$ http://law.bepress.com/expresso/eps/6>.

$70 \quad$ Elizabeth Defeis, above n 167, at 487.

71 at 490.

72 Sharon Pickering, above n 26, at 47.

73 Trafficking Protocol, above $\mathrm{n}$ 4, art 7.

74 Council Directive 2004/81/EC on the residence permit issued to third-country nationals who are victims of trafficking in human beings or who have been the subject of an action to facilitate illegal immigration, who cooperate with the competent authorities [2004] OJ L261/19 art 8. 
response to the Protocol has been criticised for making the needs of victims a secondary consideration, after the primary focus of law and order. ${ }^{75}$ Beyond an initial 45-day visa for identified victims, there is no provision for victims to remain in Australia if they choose not to participate in criminal justice proceedings. ${ }^{76}$ Similarly, the United States, has established the " $\mathrm{T}$ " non-immigration status, which is granted to foreign victims of "severe trafficking". ${ }^{77}$ Qualifying for this status depends on the willingness of victims to assist with investigations, unless they are "unable to cooperate due to physical or psychological trauma" or under 18 years of age. Additionally, there have been reports of states routinely deporting victims once they are no longer needed for prosecution purposes. $^{78}$

The prosecution model has its strengths. The successful prosecution of offenders can deter future trafficking and ensure that the perpetrators of trafficking crimes are brought to justice. ${ }^{79}$ The involvement of victims as witnesses is essential to achieving these prosecutions. A focus on law and order also avoids the risk that policy makers fear: that overly generous protective mechanisms will provide further incentives for illegal immigration.

There are, however, weaknesses to this model. There are many challenges inherent in prosecuting trafficking offences, such as the difficulty in identifying trafficking cases, the reluctance of victims to testify, and the lack of available evidence. ${ }^{80}$ This results in a low incidence of successful prosecutions compared to the volume of trafficking cases. Therefore, the emphasis, which prioritises prosecution sometimes at the expense of prosecution, appears somewhat misguided. As well, successful prosecution relies heavily upon victims coming forward and cooperating with police. The disincentives to victims doing so have already been explained. ${ }^{81}$ This makes it all the more concerning if, as the Protocol and states' domestic responses suggest, victims' protection is contingent upon providing assistance to the police. The prosecution approach is thereby limited in its

75 Marie Segrave "Order at the border: The repatriation of victims of trafficking" (2009) 32 Women's Studies International Forum 251 at 256-257.

76 See Anti-People Trafficking Interdepartmental Committee "Trafficking in Persons: The Australian Government Response 1 July 2011 - 30 June 2012” < http://www.ag.gov.au/>.

77 Trafficking Victims Protection Reauthorization Act Pub L No 109-164, title 1, § 103(c).

78 Kalen Fredette, above n 28, at 132.

79 Dina Francesca Haynes, above n 69, at 21.

80 at 22 .

81 Susan Kneebone, above n 7, at 148. 
ability to achieve its prosecution aims, because it relies on victims coming forward. It is also concerning that protection is contingent on assistance.

Moreover, in many ways the current prosecution approach to trafficking, demonstrated in the Protocol, fails to meet international human rights standards. The Protocol's provisions relating to victim protection are weak compared to the prosecution-based articles and create very few obligations for States parties to implement protective measures. It was noted during its drafting that the Protocol fails to recognise the rights of victims of human

rights violations to access appropriate remedies. ${ }^{82}$ State practice also often neglects to adequately protect victims, except as a means to facilitate prosecutions. ${ }^{83}$ In doing so, there is a risk of ongoing human rights violations for victims who are deported to dangerous situations, or for victims who remain unidentified. Thus, an alternative approach should be considered.

\section{A human rights approach}

A number of United Nations institutions have advocated taking a "human rights" approach to trafficking, calling on states to define human trafficking as a human rights abuse as well as a crime. ${ }^{84} \mathrm{~A}$ human rights approach, according to the UNHCHR: ${ }^{85}$

... means that all those involved in anti-trafficking efforts should integrate human rights into their analysis of the problem and into their responses... It means rejecting responses that compromise rights and freedoms. This is the only way to retain a focus on the trafficked persons: to ensure that trafficking is not simply reduced to a problem of migration, a problem of public order or a problem of organised crime.

This approach works from the assumption that international human rights are applicable to all people, whether or not they are citizens of the state where they find themselves. The 2011 European Union Directive on preventing and combating trafficking in human beings and protecting its victims (European Union Directive) indicates a recent shift

82 Ad-Hoc Committee on the Elaboration of a Convention Against Transnational Organised Crime, Note by the United Nations High Commissioner for Human Rights, the United Nations Children's Fund, the United Nations High Commissioner for Refugees, and the International Organisation for Migration on the draft protocols concerning migrant smuggling and trafficking in persons GA Res 254 A/AC.254/27 (1999).

83 See the examples given above from Australia and the United States.

84 See James Oatway Human Trafficking: Joint UN Commentary on the EU Directive - A Human Rights-Based Approach (UNHCR, 2011).

85 United Nations Office of the High Commissioner for Human Rights, above n 8, at 3-4. 
towards a human rights approach in the sphere of application. ${ }^{86}$ Paragraph 7 of the preamble purports to adopt an "integrated, holistic, and human rights approach" to the efforts against trafficking. The articles of the European Union Directive then prescribe protective obligations for Member States with much greater emphasis than in the Protocol. For example, art 11 stipulates: ${ }^{87}$

Member States shall take the necessary measures to ensure that assistance and support for a victim are not made conditional on the victim's willingness to cooperate in the criminal investigation, prosecution or trial.

Italy's trafficking response provides an excellent example of a human rights approach in practice. ${ }^{88}$ The basic method is to extend a humanitarian residence permit to all victims of trafficking, regardless of their involvement in the criminal justice process. ${ }^{89}$ It allows victims to choose whether or not to cooperate with law enforcement authorities, without risking their immigration status. ${ }^{90}$ Victims can choose to take the "judicial route" which involves engaging with the police, or they can choose the "social route" which simply requires that a statement be made on their behalf by an accredited non-governmental organisation. $^{91}$ Policy-makers may fear that this will discourage victims from cooperating with police investigations, but the experience with this approach in Italy indicates that this is overstated. Victims who initially opt for the "social route" gain trust in government institutions, which empowers them to later lay complaints against their traffickers. ${ }^{92}$ This prioritises victim protection and provides a means for victims to escape situations of exploitation.

86 Directive 2011/36/EU of the European Parliament and of the Council on preventing and combating trafficking in human beings and protecting its victims, and replacing Council Framework Decision 2002/629/JHA [2011] OJ L101/1.

87 (Emphasis added).

88 See European Commission "Together against Trafficking in Human Beings: Italy" $<$ http://ec.europa.eu>.

89 Legislative Decree No 286/1998 art 18.

90 European Commission, above n 88, at 2.1.

91 at 3.2 .

92 Isabella Orfano and Marco Bufo "The Italian system of assistance and integration of victims of trafficking in human beings by Associazione On the Road" <http://ec.europa.eu/antitrafficking/download.action;jsessionid=d0C3S8GGqPSQvjRV186w0kcLyBn8Lvf7GqLBnyB3R5 LPlfV8G2pp!444076514?nodePath=/National+Info+Pages/Italy/5.+RESOURCES/5.3+Reports/T he+Italian+system + of + assistance + and + integration + of + victims + of + trafficking + in + human + beings en.pdf $\&$ fileName $=$ The + Italian + system + of + assistance + and + integration + of + victims + of + trafficking + in + human+beings_en.pdf\&fileType $=$ pdf $>$ at 4 . 
Victims of trafficking suffer gross human rights violations through their forced servitude, so providing adequate protection should be a priority in any policy response. Their rights to rights to life, liberty and security of person, freedom from torture, and nonrefoulement, all protected at international law, are at stake. ${ }^{93}$ When considering New Zealand's immigration response to trafficking, a human rights approach should be adopted. Instead of simply ensuring it complies with the Protocol, New Zealand ought to pursue a human rights approach, which makes victim protection a policy priority. A comprehensive strategy to trafficking is needed, and protecting victims must be central to this. Therefore, in assessing New Zealand's trafficking response, it is necessary to reject policies that compromise rights and freedoms, and to recommend practices that focus on victim protection.

\section{Nine principles for assessing New Zealand's response}

In order to adopt a human rights approach in New Zealand, it is necessary to first determine the principles that should be guiding policy decisions, and to determine a model of best practice for a state response to human trafficking. Although the Protocol provides little in the way of binding obligations on States parties to protect the status of victims, there are a number of soft law guidelines recommended by bodies such as the UNHCHR, the United Nations Office on Drugs and Crime (UNODC), and the IOM. These guidelines, together with examples from different jurisdictions and bolstered by policy-based arguments, form the basis for the following nine principles. These principles will then be used to assess where New Zealand is meeting the standards of a human rights approach and where it is failing to do so.

\section{Broad definition of "victim"}

A "victim" of human trafficking should be defined broadly, to include any person who is a suspected victim of trafficking offences. The United Nations Basic Principles and Guidelines on the Rights of Victims (UN Principles on Victim Rights) states that victims should be treated with respect for their dignity and human rights, and that measures should be taken to ensure their safety. ${ }^{94}$ Importantly, a person is considered a victim regardless of whether the perpetrator is identified or prosecuted, and regardless of their involvement in law enforcement proceedings. ${ }^{95}$ Failing to recognise a person as a victim

93 See generally United Nations Office of the High Commissioner for Human Rights, above n 8, at 18-22.

94 Basic Principles and Guidelines on the Right to a Remedy and Reparation for Victims of Gross Violations of International Human Rights Law and Serious Violations of International Humanitarian Law GA Res 60 A/RES/60/147 (2006) at [10].

95 At [9]. 
leads to further problems. It is important that a person is considered a victim, regardless of whether his or her traffickers are identified or are the subject of prosecution or conviction. ${ }^{96}$

\section{Non-criminalisation of victims}

This principle is derived from Principle 7 of the UNHCHR Principles and Guidelines on Human Rights and Human Trafficking (the UNHCHR Principles), which states that: ${ }^{97}$

Trafficked persons shall not be detained, charged or prosecuted for the illegality of their entry into or residence in countries of transit and destination, or for their involvement in unlawful activities to the extent that such involvement is a direct consequence of their situation as trafficked persons

The UNHCHR Principles recommend that states adopt a legal framework to ensure that trafficked persons are not prosecuted, detained or punished for their status-related offences. ${ }^{98}$ The UNODC Model Law on Trafficking in Persons contains an example provision, which effectively grants victims amnesty for offences committed as a direct result of trafficking, including illegal entry or stay in a state, fraudulent travel documents and other unlawful activities that he or she committed under compulsion. ${ }^{99}$ The principle of non-criminalisation is also engaged by the EU Directive, which requires in art 8 that Member States take necessary measures not to prosecute victims of trafficking for criminal activities they have been involved in as a direct consequence of being trafficked. ${ }^{100}$

If victims face criminal or administrative sanctions for their involvement in illegal activity, they are essentially being re-victimised by the state. Moreover, the risk of facing such sanctions may deter victims from engaging with state officials, which would have disastrous consequences for the protection of victims. If a victim's criminalisation results in deportation, his or her right to non-refoulement could also be compromised.

\section{Opportunity for recovery and reflection}

All suspected victims of trafficking in persons should be given temporary immigration status so that they have the opportunity to recover from their trafficking situation and

$96 \quad$ United Nations Office of the High Commissioner for Human Rights, above $\mathrm{n}$ 8, at 73.

97 at 129.

$98 \quad$ At 131.

99 UNODC Model Law on Trafficking in Persons at 33.

100 above $\mathrm{n} 86$, art 8 . 
reflect on their options. One way that states have attempted to better protect victims in the immediate aftermath of their identification is to offer a "reflection and recovery period". This allows the person an opportunity to consider their options, including whether they wish to cooperate with authorities and engage with the criminal justice system.

The UNHCHR Principles recognise this mechanism as a positive step towards better protection for victims and something that helps to separate the investigative imperative from victim protection. ${ }^{101} \mathrm{~A}$ reflection and recovery period should be granted unconditionally, and not be dependent on a victim's cooperation with authorities. The UNODC acknowledges recovery and reflection periods as effective best practice, and provides some example provisions that ensure victims are not deported until they are given the opportunity for recovery and reflection. ${ }^{102}$ The Council of Europe Directive on the Residence Permit requires that a reflection and recovery period be granted to a person when there are reasonable grounds to believe he or she is a victim. ${ }^{103}$ A number of states have implemented some version of this measure, with periods of varying lengths. Some evidence suggests that a minimum period of three months is needed for a trafficking victim to recover the necessary cognitive functioning and emotional strength to make lucid, informed decisions about their future actions and to provide detailed evidence about their trafficking history. ${ }^{104}$

The purpose of this mechanism is to allow victims a chance to escape the power and influence of their traffickers, and the ability to make informed decisions about their future options. The provision of a recovery and reflection period helps states to avoid treating a victim exclusively as an instrument for prosecution. ${ }^{105}$

\section{Victim participation in prosecutions}

Victims should be given the opportunity to participate in the investigation and prosecution of their traffickers. The Convention against Transnational Organised Crime

$101 \quad$ United Nations Office of the High Commissioner for Human Rights, above n 8, at 151.

102 UNODC Toolkit to Combat Trafficking in Persons at 120; UNODC Model Law on Trafficking in Persons at 59-60.

103 Above $\mathrm{n} 74$, art 6.

104 See Cathy Zimmerman et al "Stolen Smiles: The physical and psychological health consequences of women and adolescents trafficked into Europe" (2006) the London School of Hygiene and Tropical Medicine at 3; Experts Group on Trafficking in Human Beings of the European Commission, above n 105, at [3]-[5].

105 Experts Group on Trafficking in Human Beings "Opinion on reflection period and residence permit" (18 May 2004) European Commission < http://ec.europa.eu/> at [1]. 
requires States parties to "enable views and concerns of victims to be presented and considered at appropriate stages of criminal proceedings against offenders."106 Moreover, under the Protocol States parties are under the obligation to provide assistance to enable them to do so. ${ }^{107}$ Principle 9 of the UNHCHR Principles and guidelines affirms this right of victims to participate in prosecutions against their traffickers, and to remain in the country during these proceedings. ${ }^{108}$

This principle recognises the important role that victims play in legal proceedings, and that they have a legitimate interest in being involved. The international community has recognised the importance of providing remedies for gross violations of human rights, and that this requires states to honour victims, including their role in the prosecution of crimes against them, and to reaffirm the principles of "accountability, justice and the rule of law." 109 The involvement of victims as witnesses is also crucial to the criminal justice process, so facilitating their involvement also serves the interests of securing prosecutions. Therefore, it is important to ensure that victims are able to participate safely and voluntarily.

To facilitate this involvement, victims need to be given all necessary information and be granted the means of remaining in the country. If their immigration status is uncertain, victims should be granted temporary residence permits such that they are able to remain in the country for the duration of the investigation and conviction. To the extent that victims need a permit to be able to present their views and concerns, there may be an obligation in the Convention and Protocol for States parties to do so. ${ }^{110}$ There are different ways of allowing victims to stay in the country for the purposes of participating: either through a special visa connected to criminal proceedings or a temporary visa granted on humanitarian grounds. It is important that participation is an option for victims, but it is equally important that this is voluntary. The opportunity for a recovery and reflection period can help ensure that any decision to participate is done so voluntarily.

\footnotetext{
$106 \quad$ Above $\mathrm{n} 4$, art 25(3).

107 Above n 4, art 6(2).

108 United Nations Office of the High Commissioner for Human Rights, above n 8, at 153.

109 Basic Principles and Guidelines on the Right to a Remedy and Reparation for Victims of Gross Violations of International Human Rights Law and Serious Violations of International Humanitarian Law, above n 94.

110 Trafficking Protocol, above n 4, art 6(2); Convention Against Organised Transnational Crime, above $\mathrm{n} 4$, art 25(3).
} 


\section{$5 \quad$ Protection not dependent on assisting authorities}

The protective mechanisms that are required in arts 6,7 and 8 of the Protocol should be provided regardless of a victim's willingness or ability to assist with police investigations or prosecutions. The UNHCHR supports this in relation to the protections in art 6 , and has stated that "separating protection and support from victim cooperation is a fundamental tenet of the human rights approach to trafficking." 111 It recommends in Principle 8 that states should protect all trafficking victims from further harm and exploitation. ${ }^{112}$ Similarly, the United Nations Secretary General has said that "States parties should ... [e]nsure victims are provided with immediate support and protection, irrespective of their involvement in the criminal justice process." "113 The UNHCHR does not go so far as to suggest that immigration status should also be granted independently of a victim's willingness or capacity to assist officials, but others have argued that it should. ${ }^{114}$ The Joint United Nations commentary on the EU Directive points out that making immigration permits conditional on cooperation with the authorities is likely to compromise a victim's rights, and is not compatible with a human rights approach. ${ }^{15}$

A victim of trafficking is also a victim of gross violations of human rights law. ${ }^{116}$ Where a victim's protection depends wholly on his or her utility for prosecutions, however, it becomes simply a means to an end, and compromises the rights of the victim. The fear of policy makers is that this would reduce the incentives for victims to assist authorities, which is essential for an effective prosecution. This consideration is valid because an important component of effectively combatting trafficking offences is the cooperation of victims.

The reasons for unconditional support are, however, much more compelling. If visas are granted only for the purpose of involvement in the criminal justice process, victims who are unable to assist in the prosecution of their exploiters may be denied immigration rights. This effectively turns the victim's immigration status into a lottery and means that

111 United Nations Office of the High Commissioner for Human Rights, above $\mathrm{n}$ 8, at 142.

112 At $142-143$.

113 United Nations Secretary-General "Improving the coordination of efforts against trafficking in persons Background paper" <https://www.un.org/ga/president/63/letters/SGbackgroundpaper.pdf $>$ at 29.

114 See for example Dina Francesca Haynes, above n 69.

115 Above $n$ 84, at 46-47.

116 Basic Principles and Guidelines on the Right to a Remedy and Reparation for Victims of Gross Violations of International Human Rights Law and Serious Violations of International Humanitarian Law, above n 94, at [8]. 
many victims could miss out on protection. ${ }^{117}$ Furthermore, there may be valid reasons for a person's unwillingness to assist authorities or to testify in the case against his or her traffickers. There is evidence that trafficking victims could suffer from Post Traumatic Stress Disorder, dissociative disorders, anxiety disorders or depression, which would make it difficult for them to engage with the authorities. ${ }^{118}$ In addition, there may tactical reasons not to condition residency on the willingness to testify: it increases the risks of false testimony, and the risk that defense counsel will challenge the veracity of a witness on the grounds that he or she is testifying solely for the purpose of securing their residency. ${ }^{119}$ Finally, the obligations to protect all victims will be impossible in some cases without first providing valid immigration status.

\section{Non-refoulement}

The principle of non-refoulement is essentially that no person should be returned to any country where he or she is likely to face persecution or torture. ${ }^{120}$ This is a clearly established rule of international law, to which New Zealand is committed through its obligation to the United Nations Convention and Protocol on the Status of Refugees (the Refugee Convention), the International Covenant on Civil and Political Rights (ICCPR) and the Convention Against Torture (CAT). ${ }^{121}$ The principle of non-refoulement should apply to victims of human trafficking, so they should not be returned to their country of origin if it would be unsafe. The eleventh UNHCHR Principle demands the safe and voluntary return of trafficking victims. ${ }^{122}$

At the point of returning a victim to their home country, states need to be aware of the risks that arise upon their return. As already briefly canvassed above, there is a real risk of victims suffering further harm, which can arise from a number of sources: ${ }^{123}$ First, it

\footnotetext{
$117 \quad$ At 38-39.

118 Hussein Sadruddin, Natalia Walter and Jose Hidalgo "Human Trafficking in the United States: Expanding Victim Protection Beyond Prosecution Witnesses” (2005) 16 Stan L \& Pol'y Rev 379 at 405 .

119 Dina Francesca Haynes, above n 69, at 38-39.

120 Guy S Goodwin-Gill The Refugee in International Law (2nd ed, Clarendon Press, Oxford, 1996) at 117.

121 United Nations Convention and Protocol on the Status of Refugees 189 UNTS 137 (opened for signature 28 July 1951, entered into force 22 April 1954); International Covenant on Civil and Political Rights 999 UNTS 171 (opened for signature 16 December 1966, entered into force 23 March 1976); Convention Against Torture 1465 UNTS 85 (opened for signature 10 December 1984, entered into force 26 June 1987).

122 United Nations Office of the High Commissioner for Human Rights, above n 8, at 175.

123 at 175.
} 
may come from authorities that punish people for offences committed in the course of their trafficking. Second, a victim can suffer further violence or threats of violence from their traffickers or associates who are in their home country. This danger is pertinent where a victim still owes money to their perpetrators or where they have facilitated investigations and prosecutions. Finally, there is a chance that victims will be stigmatised for their experience and face the rejection of their families and communities. This opens up the possibility of future harm, or in some cases the danger of being re-trafficked.

These risks highlight the need for robust procedures when it comes to repatriating victims of people trafficking. The UN Principles on Victim Rights declares that adequate reparation should be made for harm suffered, which includes the guarantee of nonrepetition of harm. ${ }^{124}$ Therefore, States parties should ensure that repatriation of victims does not result in re-trafficking. The use of a pre-return assessment, conducted on an individual basis, is a necessary precursor to repatriation. Moreover, the IOM, in its Handbook on Direct Assistance for Victims of Trafficking, acknowledges that return to a victims' country or community of origin is not always the best or desired solution. ${ }^{125}$ Therefore, to uphold the principle of non-refoulement, states need to be careful about their policies relating to the return of victims.

\section{Long-term or permanent immigration options}

If repatriation is not a safe option for victims, there needs to be an alterative option available. Residence permits or asylum should be offered to victims, irrespective of their involvement in law enforcement activities, if there is a risk that they will suffer further harm upon their return. Just because a person is not in the sort of danger envisaged by the right of non-refoulement does not mean that they are not in need of ongoing protection and support. It needs to be recognised that significant harm has already been suffered through trafficking, and that this can, to some extent, be mitigated through ongoing protection and support. Harm should therefore be viewed broadly, as including physical harm, as well as significant social stigma and economic hardship.

124 Basic Principles and Guidelines on the Right to a Remedy and Reparation for Victims of Gross Violations of International Human Rights Law and Serious Violations of International Humanitarian Law, above n 94, at [23].

125 IOM Handbook on Direct Assistance for Victims of Trafficking $<$ www.iom.int/jahia/webdav/site/myjahiasite/shared/shared/mainsite/published_docs/books/CT\%2 Ohandbook.pdf $>$ at 55 . 
The UNODC Model Law gives a list of grounds to consider when deciding whether to grant permanent or long-term residence status for victims. ${ }^{126}$ These include the risk of retaliation against a victim from family, the likelihood of facing prosecution for trafficking-related offences in the victim's country of origin, and the prospects for living a humane life and the availability of support services in their home country. The Experts Group on Trafficking in Human Beings, reporting to the European Commission, was of the opinion that a residence permit should be granted to victims for six months irrespective of their ability to assist with criminal investigation, with an opportunity for renewal. ${ }^{127}$ It goes on to recommend that a residence permit should be issued on humanitarian grounds at the expiry of the temporary permit if there are no other existing measures available for the victim. ${ }^{128}$

The vulnerability of children demands even greater concern for their safety after being rescued from a trafficking situation. The Protocol does not address the position of children, but the Legislative Guide states that adequate arrangements must be made for their safety and to protect their human rights, "in situations where the safe return of the child to his or her family and/or country of origin is not possible or where such return would not be in the child's best interest." ${ }^{29}$ The UNHCHR Principles specifically advise that where return is not safe or not in the best interests of the child, adequate care must be provided for him or her. ${ }^{130}$ This accords with the Convention on the Rights of the Child (CRC), which establishes that in all actions concerning children, the best interests of the child must be a primary consideration. ${ }^{131}$ New Zealand is party to the CRC so decisions about a child victim's immigration status must be made with consideration of their best interests, which may include providing long-term residence.

\section{Provision of information and assistance}

In order to make protective measures effective, victims must be made aware of their options. Once they are given the opportunity for recovery and reflection, the availability of other protective mechanisms, including immigration options, must be presented to them. The IOM Handbook discusses referring victims to asylum procedures or other

\footnotetext{
$126 \quad$ Above $\mathrm{n}$ 99, at 61.

127 Experts Group on Trafficking in Human Beings above n 105, at [4].

128 At [6].

129 United Nations Office on Drugs and Crime Division for Treaty Affairs Legislative Guides, above n 39, at [67].

130 United Nations Office of the High Commissioner for Human Rights, above n 8, at 165.

131 Convention on the Rights of the Child 1577 UNTS 3 (opened for signature 20 November 1989, entered into force 2 September 1990) art 3.
} 
specific residency options, ${ }^{132}$ and the UNODC Toolkit notes that helping victims seek asylum may be a crucial aspect of assistance procedures. ${ }^{133}$

It is important to remember that victims of trafficking are non-citizens who will be unfamiliar with New Zealand's legal systems. There will also likely be language barriers, meaning that victims may not know where to seek help. The danger is that unassisted victims will fall through the cracks and end up being deported to dangerous situations. For this reason, the residency options need to be made clear to victims, and legal advice should be available. ${ }^{134}$

In Canada, officials are required to explain to victims that they are eligible to apply for a work permit, and that a health program is available to them. ${ }^{135}$ Officials must also explain that there are other options open to victims for remaining in Canada. These include stays of removal, refugee or protection claims, application for humanitarian consideration, and a pre-removal risk assessment. The processes for attaining immigration status and the conditions for various residence options should be clearly set out in law so that a person can know in advance if they will be able to avail themselves on these protections.

\section{Decisions should be subject to appeal or review}

Finally, decisions that are made about a person's identity as a victim, or about their immigration status, should be subject to appeal or judicial review. This ensures that procedures are transparent and carried out in accordance with law. The UNODC Model Law, in its example provision for a recovery and reflection period, stipulates that decisions on granting this period should be appealable. ${ }^{136}$ Ensuring that appeals are available for such decisions adds another safeguard against the risk that a victim will be misidentified and deported to a dangerous or life-threatening situation.

\section{Assessing New Zealand's Trafficking Response}

There is no doubt that officials working in New Zealand seek to protect victims of human trafficking through immigration policy, and the current approach may be capable of extending protection to victims. It is, however, important that the immigration policy

\footnotetext{
$132 \quad$ Above $\mathrm{n} 125$, at 55.

133 UNODC Toolkit to Combat Trafficking in Persons, above n 102, at 118.

134 James Oatway, above $\mathrm{n} 84$, at 59.

135 Citizenship and Immigration Canada "IP 1 Temporary Resident Permits" (19 June 2007) at [16.4][16.5].

136 UNODC Model Law, above n 99, at 59-60.
} 
adopted in New Zealand is sufficiently robust to ensure there is no risk of victims missing out on the protection to which they are entitled. Therefore, it is important that New Zealand's trafficking response adheres to the principles elucidated above. This part will first consider New Zealand's policy initiatives in response to trafficking, and whether they meet the nine principles of human rights approach. After identifying the gaps in this scheme, it will assess whether they can be filled by alternative methods: first through asylum procedures and secondly through humanitarian grounds of appeal.

\section{A Implementation of the Protocol}

New Zealand signed the Protocol on 14 December 2000 and ratified it on 19 July 2002. ${ }^{137}$ According to the National Interest Analysis completed prior to ratification, the obligations of the Protocol did not require New Zealand to make any legislative changes in relation to victim protection. ${ }^{138}$ However the Analysis did acknowledge that policies, procedures and programmes may have needed adjusting to reflect best practice. ${ }^{139}$ The main policy response was the creation of the Plan of Action to Prevent People Trafficking (Plan of Action), introduced by the Department of Labour together with the Inter-agency Working Group on People Trafficking. ${ }^{140}$ The Plan of Action established a three-tiered approach that is consistent with the purposes of the Protocol: preventing trafficking, prosecuting traffickers and protecting victims.

The approach to victim protection under the Plan of Action has been an amalgamation of existing law, which provides a relatively flexible framework to respond to trafficking as it occurs. One element of the Plan of Action is the assisted repatriation of victims. The National Interest Analysis states that the existing policy was generally for overstayers to be removed through a managed process. ${ }^{141}$ According to the Plan of Action, repatriation and settlement decisions are made on "a case-by-case basis, taking into account the specific circumstances and needs of the victim as well as humanitarian and compassionate considerations." ${ }^{142}$ Where a victim agrees to be repatriated, the Department of Labour will conduct a humanitarian assessment and arrange the

\footnotetext{
137 United Nations Treaty Collection "Protocol to Prevent, Suppress and Punish Trafficking in Persons, Especially Women and Children details" $<$ http://treaties.un.org/Pages/ShowMTDSGDetails.aspx?src=UNTSONLINE\&tabid=2\&mtdsg_no $=$ XVIII-12-a\&chapter=18\&lang=en\#Participants $>$ (last updated 5 October 2013).

138 Ministry of Foreign Affairs and Trade, above n 5, at [19].

139 at [25].

140 Department of Labour, above $\mathrm{n} 35$.

141 Ministry of Foreign Affairs and Trade, above $\mathrm{n} 5$.

142 at 16.
} 
repatriation. ${ }^{143}$ The Ministry of Foreign Affairs and Trade also plays a role in liaising with the victim's home country, ensuring that there is better protection for the victim upon return. The Plan of Action appreciates the role that victims may play in the investigation and prosecution of trafficking crimes, and to that end recognises that a victim may need to remain in New Zealand for some time. ${ }^{144}$ Additionally, if returning a victim to their country of origin is considered too dangerous, the Department of Labour can look at options for long-term immigration solutions. Both of these scenarios are to be accommodated from within the range of existing permits. ${ }^{145}$

There are a number of existing visa options available for victims of trafficking that already exist in New Zealand's immigration law. Immigration Instructions provide specifically for "People Trafficking" victims to be eligible for residence visas or temporary visitor, work and study visas in certain cases. ${ }^{146}$ The Minister has the absolute discretion to grant a temporary visa or a residence visa to any person who is prohibited from applying due to his or her illegal immigration status.

Immigration instructions create special temporary visa categories for trafficking victims. This depends first on certification from the police that someone is a victim of trafficking. ${ }^{147}$ Certification is based on an assessment of available evidence and witness statements and will be issued where there is a reasonable suspicion that the person was trafficked to New Zealand. ${ }^{148}$ The certification confirms that a police investigation is underway, that the person is suspected of being a victim, and that they have not obstructed police investigation. Children, defined as persons under the age of 18 at the time of their identification as a victim, ${ }^{149}$ may be granted a visitor visa valid for 12 months if they are certified as a victim of trafficking. ${ }^{150}$ They may also be granted a

143 Department of Labour, above n 35, at 17.

144 At 17.

145 At 17 .

146 Immigration New Zealand Operational Manual "Residence" above n 9; Immigration New Zealand Operational Manual "Temporary entry" (1 July 2013) $<$ http://www.immigration.govt.nz/migrant/general/generalinformation/operationalmanual/>.

147 Immigration New Zealand Operational Manual "Temporary entry", above n 146, at V3.135, WI16.1, and U10.5.

148 New Zealand Police "New Zealand Police Manual: People Trafficking and Migrant Smuggling" (Obtained under Official Information Act 1982 Request the New Zealand Police) at 20.

149 Immigration New Zealand Operational Manual "Temporary entry", above n 146, at V3.315.

150 at $\mathrm{V} 3.315$. 
permit to study for 12 months. ${ }^{151}$ For adults, a work visa may be granted for 12 months once a person has been certified by the police as a victim of trafficking. ${ }^{152}$

In the long term, there are special residence visa options for victims of trafficking who are unable to return home due to danger of re-victimisation or stigma and financial hardship as a result of their trafficking experience. ${ }^{153}$ In order to qualify for a residence visa, a person must hold a special temporary visa (outlined above) and be certified by the police as a victim of trafficking. Additionally, adults must have certification from the police affirming that they have not obstructed investigations while on a temporary visa. ${ }^{154}$ This follows from the fact that one of the purposes of the visa is to aid the prosecution of offenders. ${ }^{155}$ Furthermore, to be eligible for a residence visa, victims must give evidence of their inability to return to their home country. They must provide documentation or information showing that they would be: ${ }^{156}$

(i) endangered; or

(ii) at risk of being re-victimised; or

(iii) at risk of suffering significant social stigma and financial hardship as a consequence of being trafficked.

Finally, to qualify for a residence visa, a victim must meet the usual health and character requirements for residence applicants. ${ }^{157}$ Unlike for persons with refugee or protected person status, there is no automatic waiver of the health requirements. ${ }^{158}$ Therefore, an applicant must show that they are: ${ }^{159}$

(i) unlikely to be a danger to public health; and

(ii) unlikely to impose significant costs or demands on New Zealand's health services or special education services; and

\footnotetext{
151 at $\mathrm{U} 10.5$.

152 at WI16.5.

153 Immigration New Zealand Operational Manual "Residence" above n 9, at S4.15.1(a).

154 aat $\mathrm{S} 4.15 .5(\mathrm{a})(\mathrm{iii})$ and $\mathrm{S} 4.15 .5(\mathrm{~b})$.

155 at $\mathrm{S} 4.15 .1(\mathrm{~b})$.

156 at $\mathrm{S} 4.15 .10$.

157 at $\mathrm{S} 4.15 .5(\mathrm{a})(\mathrm{v})$.

158 Immigration New Zealand Operational Manual “Administration" (1 July 2013) $<$ http://www.immigration.govt.nz/migrant/general/generalinformation/operationalmanual/>, at A4.70. at $\mathrm{A} 4.10(\mathrm{~b})$.
} 
(iii) able to undertake the work on the basis of which they are applying for a visa, or which is a requirement for the grant of the visa.

For child victims, any decisions relating to their repatriation or residence will be based on the best interests of the child. ${ }^{160}$

\section{B Adequacy of trafficking response}

According to the criteria set out in Part III, New Zealand's response to trafficking must meet the nine principles of a human rights approach to protecting trafficking victims. The principles are met in most cases: for most victims, the nine principles would be met. Under immigration policy, victims should generally be recognised as such and would therefore not be subject to criminal sanctions. All recognised victims are then granted a substantial period for recovery and reflection through the 12 month temporary visa scheme. At this stage, a victim's protection and the provision of services do not depend on cooperation with the police. Furthermore, victims are given the opportunity to participate in the investigation and prosecution of their traffickers, and are assisted in doing so. For the most part, victims will be able to obtain long-term residence status, either through qualifying for a residence visa, through asylum mechanisms, or through a humanitarian appeal. Where a victim is able to utilise either of these procedures, there will be no problems meeting the principles of a human rights approach. There are, however, three major gaps in the visa scheme, which lead to the compromise of victim's rights and breach some of the principles.

\section{Lack of police certification}

A victim must be certified as a trafficking victim by the police in order to qualify for a range of support services, including a temporary or residence visa. ${ }^{161}$ While temporary visas do not explicitly require victims to cooperate with law enforcement, police certification does require that the police are investigating a crime of trafficking. ${ }^{162}$ If a victim is unable to identify his or her traffickers, or the police are unable to connect a victim to a perpetrator, he or she may therefore miss out on the protections available for trafficking victims. It is of note that no cases of trafficking have been recorded since it became an offence in 2002. ${ }^{163}$ This may be because no trafficking offences have come to

$160 \quad$ New Zealand Police, above n 148, at 18.

161 See Immigration New Zealand Operational Manual “Temporary entry”, above n 146, at V3.135, WI16.1, and U10.5.

162 New Zealand Police, above n 148, at 20.

163 Letter from B Perry (Detective Inspector, Acting National Manager New Zealand Police National Criminal Investigations Group) in response to request for information, above n 13. 
light since then, but there are strong indications that trafficking is taking place in New Zealand on some scale. One explanation is that offenders are being charged with other related offences or that there has been insufficient evidence to prosecute for trafficking. Either way, the lack of investigation into trafficking offences means that victims are not being certified. Therefore, a victim may not be identified at the outset or entitled to the special immigration protections and options consequent on certification as a victim.

A number of the principles of the human rights approach to trafficking are breached for victims in this position. The first principle, that "victim" should be defined broadly is therefore broke. Principle 2, that victims should not face criminal sanctions for their involvement in trafficking activity, could also be broken because where a person is not identified as a victim of trafficking, he or she may be subject to deportation for immigration offences. This failure to identify victims through lack of police certification leads to the breach of other principles. The principle that a victim should be given the opportunity for recovery and reflection is not met for victims who are not certified and do not qualify for a temporary visa. The same is true for the principles of non-refoulement and long-term residency. Without police certification, a victim does not qualify for a temporary or residence visa, and may be deported to dangerous circumstances, unless he or she can find alternative means of protection through asylum or humanitarian processes. Principle 4, that protection should not depend on cooperation with law enforcement authorities, is also infringed. If a victim is not involved in police investigations, he or she may not be police-certified as a victim, and would therefore miss out on the protection mechanisms available to trafficking victims. Finally, the last principle, that decisions should be appealable, is not upheld because there is currently no procedure for a potential victim to appeal a decision about his or her status.

\section{Non-cooperation}

If an adult victim obstructs police investigations, he or she will not qualify for a residence visa after the initial 12-month temporary visa. ${ }^{164}$ Given that the involvement of victims is often essential for successful criminal investigations and prosecutions, it is likely that where a victim refuses to be involved in criminal investigations the police will deem this an obstruction. But there are many valid reasons that a victim might have for not wanting to participate with criminal investigations and prosecutions. ${ }^{165}$ In particular, they may fear the retribution of their traffickers. If a victim chooses not to assist the police, he or

164 Immigration New Zealand Operational Manual "Residence" above n 9, at S4.15.1(a)(iii).

165 See Dina Francesca Haynes, above n 69, at 38-39; Hussein Sadruddin, Natalia Walter and Jose Hidalgo, above n 118, at 405. 
she will lose the possible protection of a residence visa. This infringes the principle that protection should not depend on a victim's involvement with law enforcement authorities. If a person faces deportation as a result of this limitation, the principles of non-refoulement and long-term residence could also be breached. For victims in these circumstances, further protection will depend on their ability to satisfy asylum or humanitarian grounds, which will be discussed below.

\section{Failed health and character requirements}

A residence visa for victims of human trafficking depends on being able to satisfy the health requirements of residence visas generally. ${ }^{166}$ While these requirements are automatically waived for refugees and protected persons, a trafficking victim must meet the strict health standards set by Immigration instructions. ${ }^{167}$ A person will not meet health requirements if he or she is considered to be of significant cost to the New Zealand health system because of having conditions such as a psychiatric illness or addiction, a physical disability, hepatitis or HIV. ${ }^{168}$ A person who has suffered physical and

psychological trauma through trafficking and exploitation may, therefore, be excluded. If a victim does not qualify for residency due to health conditions, and there are sufficient risks to the victim upon their return, the principles of non-refoulement and long-term residence are not being kept. After the initial 12 month temporary visa, a victim should be able to remain in New Zealand if return would be dangerous, but he or she will be unable to do so under a trafficking victim residency visa.

\section{Asylum procedures}

There may be victims who do not satisfy the requirements for temporary or residence visas under Immigration instructions, either because they do not receive police certification of their victim status, because they are not willing to participate in law enforcement procedures, or because they do not meet the health requirements for residence visas. In these cases, there are gaps in New Zealand's trafficking policy when assessing it according to human rights principles. However, these gaps may be filled by New Zealand's asylum mechanisms. In a number of jurisdictions, victims of trafficking have successfully used existing asylum frameworks to find protection in a receiving state. ${ }^{169}$ Some victims who fear returning to their country of origin because of the risk of further harm may be able to claim refugee or protected person status.

166 Immigration New Zealand Operational Manual "Residence" above n 9, at S4.15.1(a)(v).

167 Immigration New Zealand Operational Manual “Administration”, above n 158, at A4.60.

168 at A4.10.1.

169 See for example $A Z$ (Trafficked women) Thailand CG [2010] UKUT 118 and Talo v Minister of Citizenship and Immigration [2012] FCJ 478. 


\section{Trafficking victims as refugees}

New Zealand is party to the Refugee Convention, from which it derives the obligation to accept refugees seeking asylum in New Zealand. ${ }^{170}$ Whether a trafficking victim will be recognised as a refugee in New Zealand depends on the definition found in art $1 \mathrm{~A}(2)$ of the Refugee Convention. Accordingly, a refugee is a person who: ${ }^{171}$

Owing to well-founded fear of being persecuted for reasons of race, religion, nationality, membership of a particular social group or political opinion, is outside the country of his nationality and is unable or, owing to such fear, is unwilling to avail himself of the protection of that country; or who, not having a nationality and being outside the country of his former habitual residence as a result of such events, is unable or, owing to such fear, is unwilling to return to it.

The application of this definition is now well established in New Zealand's refugee law jurisprudence. Refugee Appeal No 70074/96 Re ELLM established that the two principle issues to be determined are: ${ }^{172}$

(a) Objectively, on the facts as found, is there a real chance of the appellants being persecuted if returned to the country of nationality?

(b) If the answer is yes, is there a Convention reason for that persecution?

The first major hurdle to overcome in establishing refugee status is showing that there is a "well-founded fear" of persecution. This test is a wholly objective one; the experience and actual fears of a victim, however genuine, are irrelevant. ${ }^{173}$ However, in the cases of trafficking victims, fear of ill treatment upon their return is likely to be well founded. As discussed earlier, victims often face threats of ill treatment in their home country when they are returned. This threat can manifest in various forms, one of which is retrafficking. Establishing that there is a "well-founded fear" is a fact-specific inquiry. In the United Kingdom case of $A Z$ (Trafficked women) Thailand CG ("AZ") the Court did not accept that all women who have been trafficked are inherently at risk of retrafficking, but the Court did agree that the appellant faced such a risk. ${ }^{174}$ In light of the emerging information about the dangers of re-trafficking and other harm that may be

170 The Refugee Convention, above $\mathrm{n} 121$.

171 Art 1(a)(2).

172 Refugee Appeal No 70074/96 Re ELLM Refugee Status Appeals Authority, 17 September 1996 at [40].

173 Refugee Appeal No 76044 Refugee Status Appeals Authority, 11 September 2008 at [57].

174 Above n 169, at [110]. 
inflicted on victims upon return to their countries of origin, the fears of many trafficking victims will often be well-founded so that the first limb of the test for refugee status is made out.

The claimant must then establish that the threatened harm reaches the requisite threshold. It must be "persecution", which is the combination of a sustained or systemic violation of basic human rights, or "serious harm", coupled with the failure of state protection. ${ }^{175}$ In many situations it would be easy to establish that there is a risk of serious harm, because the threat of re-trafficking or other forms of retribution from traffickers will involve significant levels of harm. It is worth noting that art 8 of the ICCPR prohibits all forms of slavery and servitude. ${ }^{176}$

There may, however, be cases where the well-founded fear does not correspond to "serious harm". For example, victims of trafficking may fear returning to a situation where they would face economic hardship or social stigma as a result of their experience. This sort of harm would not be sufficient for a refugee claim, because it does not amount to persecution, and New Zealand does not accept as refugees those fleeing economic hardship. ${ }^{177}$

In cases where the agent of persecution is not the state, as in most trafficking cases, the serious harm must be coupled with a failure of state protection. ${ }^{178}$ The question to be asked is whether the protection available would reduce the risk of harm below the threshold of a "real risk" of serious harm. ${ }^{179}$ There are four situations where the state could be said to fail in its protection obligations: (a) where persecution is committed by the state concerned; (b) where persecution is condoned by the state; (c) where persecution is tolerated by the state; and (d) where persecution is neither condoned nor tolerated but is present due to the state's refusal or inability to provide sufficient protection. ${ }^{180}$ According to the United Nations High Commissioner for Refugees (UNHCR) guidelines: ${ }^{181}$

175 Refugee Appeal No 76044, above n 173, at [62].

176 Above n 121.

$177 \quad B G$ (Fiji) [2012] NZIPT 800091 at [92].

178 Refugee Appeal No 76044, above n 173, at [68].

179 at [63].

180 at [64].

181 UNHCR "Guidelines on International Protection: The Application of Article 1A(2) of the 1951 Convention and/or 1967 Protocol relating to the Status of Refugees to victims of trafficking and persons at risk of being trafficked" (2007) 19 Int'l J Refugee L 372 at [23]. 
The mere existence of a law prohibiting trafficking in persons will not of itself be sufficient to exclude the possibility of persecution. If the law exists but is not effectively implemented, or if administrative mechanisms are in place to provide protection and assistance to victims, but the individual concerned is unable to gain access to such mechanisms, the State may be deemed unable to extend protection to the victim, or potential victim, of trafficking.

This is an inquiry that depends on evidence from the country to which a victim will be returned. In the Canadian case of Talo $v$ Minister of Citizenship and Immigration, the Court found there were real doubts as to whether protection from trafficking exists for women in Albania after reviewing country evidence. ${ }^{182}$ Similarly in the United Kingdom, the Court in $A Z$ accepted that the State of Thailand did not provide sufficient protection to alleviate the risks to the appellant. ${ }^{183}$ Therefore, the answer to this question will depend on the conditions in the state to which the victim would be returned.

Not all persecution will give rise to a bona fide refugee claim; the reason for that persecution must be one specified in the Convention. According to the Immigration Protection Tribunal, it is sufficient that the Convention ground is a contributing cause to the persecution. ${ }^{184}$ There may be some cases where the race, nationality or political opinion of an individual contributes to the risk of being trafficked, but the most likely ground will be that of a "particular social group". New Zealand jurisprudence has followed the Canadian approach to finding a particular social group, which is articulated in Attorney-General $v$ Ward. ${ }^{185}$ The identity of the group must be: ${ }^{186}$

...a shared defining characteristic that is either innate or unchangeable, or if voluntary association is involved, where that association is for reasons so fundamental to the human dignity of members of the group that they should not be forced to foresake the association.

The UNHCR Guidelines identify two possible groups with which victims of trafficking in persons might identify. ${ }^{187}$ Both groups are based on innate or unchangeable characteristics. The first, women in the country of origin, is a group that might be used

$182 \quad$ Above $\mathrm{n} 169$.

183 Above n 169, at [121].

184 Refugee Appeal No 76044, above n 173, at [68].

185 [1993] 2 SCR 689.

186 at 75.

187 UNHCR, above n 181, at [38]-[39]. 
where persecution is gender-related. This is a well-established social group in New Zealand. The second possible group is former victims of trafficking. For example, in $A Z$ (Trafficked women) Thailand $C G$, the social group that the appellant belonged to was "young women who have been victims of sexual exploitation." 188 The factors that give rise to a risk of serious harm are those that stem from a trafficking experience, and therefore this second group is likely to be appropriate in most cases.

It is likely that there will be trafficking cases where the victim meets the requirements of the Refugee Convention definition, as demonstrated by the experience of other jurisdictions. UNHCR Guidelines recognise that a trafficking victim is likely to have well-founded fears of serious harm, ${ }^{189}$ and he or she will be a member of a particular social group based on the past trafficking experience.

There may, however, be situations where a victim fears returning home, but there is no evidence that they will suffer further harm, or where the threatened harm does not meet the "serious" threshold. In response to this, the UNHCR has recommended that states recognise victims even if their fear of persecution is based solely on an isolated past experience. ${ }^{190}$ This is based on the theory that, in certain cases of extreme abuse, it must be recognised that psychological damage may make it intolerable to return to the country of origin. The UNHCR advises that in these cases courts should be prepared to acknowledge the ongoing nature of the persecution. ${ }^{191}$ In other jurisdictions, the existence of past persecution has been deemed sufficient for an asylum claim, often termed "humanitarian asylum". ${ }^{192}$ This approach has not, however, been adopted by the Immigration Protection Tribunal in New Zealand. It has recently affirmed that refugee status determination is forward looking, and there must be an assessment of the risk of future persecution. ${ }^{193}$ The existence of past persecution is not determinative of future persecution. ${ }^{194}$ Extending refugee protection to those who have no fear of future persecution is inconsistent with the premise of the Refugee Convention, which is concerned with protecting people from future persecution, and it appears that decision makers and courts are not willing to recognise this as a valid refugee claim.

\footnotetext{
$188 \quad$ above $\mathrm{n} 169$, at [140].

189 UNHCR, above $\mathrm{n}$ 181, at [23].

190 at [16].

191 at [16].

192 See Susannah C Vance "An Enduring Fear: Recent Limitations on the Past Persecution Ground for Asylum” (2003) 91 Ky LJ 957 at 963.

$193 \quad A C($ Egypt) [2011] NZIPT 800015 at [91].

194 At [92].
} 


\section{Complementary protection}

Complementary protection extends the principle of non-refoulement based on international obligations from other international human rights instruments. ${ }^{195} \mathrm{New}$ Zealand has codified its obligations under art 3 of the CAT and art 7 of the ICCPR in ss 130 and 131 of the Immigration Act, creating a status for "protected persons":

130 Recognition as protected person under Convention Against Torture

(1) A person must be recognised as a protected person in New Zealand under the Convention Against Torture if there are substantial grounds for believing that he or she would be in danger of being subjected to torture if deported from New Zealand.

131 Recognition as protected person under Covenant on Civil and Political Rights

(1) A person must be recognised as a protected person in New Zealand under the Covenant on Civil and Political Rights if there are substantial grounds for believing that he or she would be in danger of being subjected to arbitrary deprivation of life or cruel treatment if deported from New Zealand.

Complementary protection has helped achieve a more holistic framework, filling gaps left in the refugee framework. In particular, there is no need to connect ill treatment to a person's race, religion, nationality, membership to a particular social group or political opinion. As will be seen, however, complementary protection is unlikely to assist victims who fail to satisfy the refugee definition.

A victim of trafficking in persons may qualify as a protected person in New Zealand if he or she can demonstrate that they are in danger of being subject to cruel treatment, for example, through re-trafficking. This danger need not emanate from the state because the Immigration and Protection Tribunal has applied s 131(1) in cases where the persecution emanates from a non-state agent. ${ }^{196}$ Pursuant to s 131(6) of the Immigration Act "cruel treatment" means cruel, inhuman or degrading treatment or punishment. The Immigration Protection Tribunal has determined that this is not a lower threshold of harm than exists in the refugee context. ${ }^{197}$ Therefore, if a claimant were not able to establish a risk of "serious harm", nor would he or she be able to establish that there is a danger of cruel

195 Udara Jayasinghe and Sasha Baglay "Protecting Victims of Human Trafficking Within a 'NonRefoulement' Framework: is Complementary Protection an Effective Alternative in Canada and Australia" [2011] 23 Int'l J Refugee L 489 at 506.

$196 \quad A C$ (Russia) [2012] NZIPT 800151 at [87].

$197 \quad A C$ (Syria) [2011] NZIPT 800035 at [131]. 
treatment. The Tribunal has also held that the "in danger" standard for cruel treatment is analogous to the "real risk" standard under the Refugee Convention. ${ }^{198}$ Complementary protection does not, therefore, assist where refugee status is denied due to an inability to demonstrate a well-founded fear of harm.

\section{Adequacy of asylum processes}

A victim who cannot demonstrate a well-founded fear of serious harm, or is not in danger of cruel treatment, will not have a successful asylum claim in New Zealand. A victim may not qualify for refugee or protected person status despite fearing ill treatment in their home country. It is accordingly evident that the asylum process will not entirely compensate for deficiencies or gaps in the immigration options available to trafficking victims. In cases where victims of trafficking qualify for either trafficking visas or refugee status, New Zealand will infringe the principle of long-term residence, which guarantees continued protection for victims who would suffer physical harm, stigma or financial hardship if returned.

Additionally, the principle that victims should be made aware of all options available to them is not being currently met. There is no indication that immigration officials are required to refer victims to asylum procedures in the case that they do not meet visa requirements, or that those victims are assisted with the process.

\section{Humanitarian grounds}

If a person is unlawfully in New Zealand for any reason, he or she is liable to be deported according to s 154 of the Immigration Act 2009. Therefore, if a victim of trafficking is not granted a residence or temporary visa and is unable to establish his or her status as a refugee or protected person, he or she will be liable for deportation. There are, however, two mechanisms under the Immigration Act that could provide a way around this liability for victims of trafficking. This first is the right of appeal against deportation decisions on humanitarian grounds, ${ }^{199}$ and the second is the broad discretion for immigration officers to cancel a deportation order. ${ }^{200}$ The two procedures will be considered in turn.

198 AC (Russia), above n 196, at [86].

199 s 154(2) and 206.

200 s 177. 


\section{Humanitarian appeals}

An appeal on humanitarian grounds is often a last resort procedure, which may take place simultaneously with a refugee or protection determination or appeal. ${ }^{201}$ Importantly, the appeal must be brought within 42 days of a deportation order being made. ${ }^{202}$ Section 207(1) of the Immigration Act provides:

The Tribunal must allow an appeal against liability for deportation on humanitarian grounds only where it is satisfied that-

(a) there are exceptional circumstances of a humanitarian nature that would make it unjust or unduly harsh for the appellant to be deported from New Zealand; and

(b) it would not in all the circumstances be contrary to the public interest to allow the appellant to remain in New Zealand.

Therefore, the Tribunal must balance the individual interests against public interests to decide whether to allow the appeal. In Galanova $v$ Minister of Immigration, the Immigration and Protection Tribunal considered the application of s 207 and its relationship to the equivalent provision in s 47(3) of the Immigration Act 1987, which has been replaced by the 2009 Act. $^{203}$ The Tribunal made it clear that the Supreme Court's reasoning in Ye v Minister of Immigration around the application of s 47(3) of the 1987 Act could be applied to s 207 of the 2009 Act. ${ }^{204}$ The Supreme Court in that case discussed three elements that were necessary to satisfy s $47(3) .{ }^{205}$ First, there must be exceptional circumstances giving rise to the claim. Justice Tipping, who delivered the majority judgment, explained that this does not require something unique or rare, rather it must be, "truly an exception rather than the rule." ${ }^{" 206}$ Second, the circumstances must be humanitarian in nature. Justice Tipping, in describing this element, pronounces that it is easy to identify, but difficult to define. ${ }^{207}$ In Galanova $v$ Minister of Immigration, the Tribunal explained that the phrase is "uncontroversial", and one that had not required indepth consideration by the Removal Review Authority in 14 years. ${ }^{208}$ Finally, the

\footnotetext{
201 Timothy P Fadgen and Guy Charlton "Humanitarian Concerns and Deportation Orders under the Immigration Act 2009: Are International Obligations Enough Protection for the Immigrant with Mental Illness?" (2012) 43 Victoria U Wellington L Rev 423, at 443.

202 Immigration Act 2009, s 154(2) and (4).

203 [2012] NZIPT 500426.

204 At [40].

205 Ye v Minister of Immigration [2010] 1 NZLR 104 (SC) at [34].

206 At [34].

207 At [34].

208 Above n 203, at [46].
} 
circumstances must be those that cause injustice or undue harshness. ${ }^{209}$ There is always some harshness involved in removing an over-stayer from New Zealand, but the harshness must go beyond that which is acceptable for the integrity of New Zealand's immigration system. ${ }^{210}$

There will be limited cases where a victim does not meet the criteria to qualify for residency under different mechanisms, so their situation could be said to be the exception rather than the rule. Additionally, the circumstances of a victim will certainly be humanitarian in nature. Where a person has faced exploitation such that he or she could be considered a victim of trafficking, a desire to avoid deportation will nearly always have a humanitarian element. The injustice or undue harshness element will be very factspecific inquiry and will depend on the reasons that a victim is appealing the deportation decision. Under the 1987 Act, the Tribunal was required to have regard to a list of factors in s 22(6) when deciding whether there would be undue harshness or injustice. The Tribunal in Galanova $v$ Minister of Immigration found that those factors remained relevant to a decision under the 2009 Act, bearing in mind that it entails a non-exclusive list. ${ }^{211}$ For example, the appellant's age will be a relevant factor. ${ }^{212}$ If a victim fears persecution or stigma upon return to a country from he or she was trafficked, injustice is likely to be present.

The second part of the test is whether, in the circumstances, it would be contrary to the public interest to allow the appellant to remain in New Zealand. ${ }^{213}$ For example, the importance of maintaining the integrity of the immigration system or preventing the risk of future offending would indicate that allowing the appellant to remain in New Zealand would not be in the public interest. ${ }^{214}$ However, there are also positive public interest considerations that may be relevant. For example, the Tribunal considered the interest of maintaining family unity a positive public interest. ${ }^{215}$ The factors that weigh in support of deportation will depend on the particular case and whether there is a risk that the victim will participate in criminal offending or otherwise present a risk to New Zealand's security. In the case of a trafficking victim, the goals of protecting victims of trafficking and aiding prosecution of trafficking offences would likely weight the public interest in

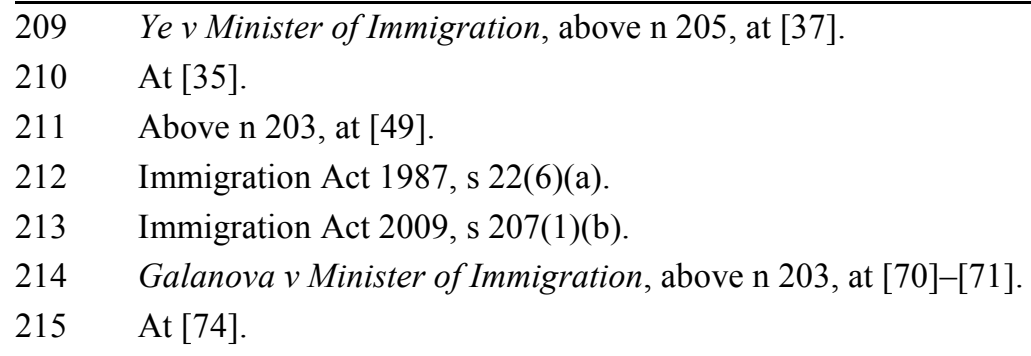


favour of allowing an appellant to remain in New Zealand. It is likely, therefore, that an appeal pursuant to $\mathrm{s} 207$ would assist a trafficking victim.

\section{Section 177 Discretion}

The Immigration Act contains a broad discretion for immigration officers to cancel a deportation order. ${ }^{216}$ It cannot be applied for but an immigration officer must consider it if a person provides information to the officer concerning his or her personal circumstances that relate to New Zealand's international obligations. ${ }^{217}$ The officer can make any decision that he or she thinks fit and is not obliged to consider any particular factors or apply any tests, apart from considering relevant international obligations. ${ }^{218} \mathrm{In}$ particular, there is no obligation to apply the test set out in s 207 for determining humanitarian appeals. ${ }^{219}$ This carve-out was a legislative response to the Supreme Court's decision in Ye v Minister of Immigration, which required officials to consider the criteria for humanitarian appeals when exercising the discretion to cancel a deportation order. ${ }^{220}$

Immigration officials are explicitly required to consider New Zealand's international obligations when exercising his or her discretion to cancel a deportation order. ${ }^{221}$ This includes New Zealand's obligations under the Refugee Convention and the ICCPR and CAT, which would require an assessment of whether the deportation order would breach the protection against refoulement. Moreover, where children are involved, the CRC must be considered. The Protocol itself is an international obligation that must be considered, but there is no obligation under the Protocol to refrain from deportation.

There are no rights of appeal against a decision made pursuant to s 177 and, under the amended 2009 Act, the scope of review for such decisions is significantly restricted. ${ }^{222}$ Section 177(4)(a) expressly states that the decision-maker is not required to give reasons for his or her decision. The immigration officer need only record the international obligations that he or she has regard to and the facts about the person's circumstances. ${ }^{223}$

\footnotetext{
$216 \quad$ Immigration Act 2009 s 177.

217 s 177(2).

218 s 177(3).

219 s 177(3)(b)(i).

220 Ye v Minister of Immigration, above n 205, at [28].

221 S 177(2).

222 Babulal v Chief Executive of Labour HC Auckland CIV-2011-404-1773, 29 September 2011, at [21].

223 Immigration Act 2009, s 177(5).
} 
This minimal record-keeping burden indicates that the decision is not one to which the courts will give a "hard look" in judicial review. ${ }^{224}$

\section{Adequacy of humanitarian appeals and discretion}

Trafficking victims are likely to be successful in an appeal on humanitarian grounds, and in many cases it would be a more appropriate mechanism than an asylum claim because it takes into account a broader set of circumstances than the risk of future persecution. However, there are some issues with relying on humanitarian grounds in the case of a trafficking victim. First, the principle that a victim should be given all the information and assistance with regards to his or her options is not met by the appeal and discretion procedures. As with asylum claims, there is no indication that victims would routinely be directed towards making a humanitarian appeal. An additional complication is the strict time limit placed on the appeal process, which may bar some from the protection who are not immediately made aware of the option.

Moreover, relying on an appeal process is inherently problematic because it anticipates that the victim has already been subject to a deportation order. Part of the information and assistance principle includes knowing in advance whether the protection will be available. A goal of regularising victims' immigration status is to provide security from the fear of deportation. The substantial degree of discretion available in both processes makes it difficult to predict whether a victim will be successful in an appeal. The inability to meaningfully review decisions made pursuant to the $\mathrm{s} 177$ discretion to cancel deportation orders also breaches the principle that decisions should be appealable.

\section{Recommendations}

The assessment of New Zealand's immigration response to trafficking has shown that there are a number of gaps in victim protection, which breach the principles identified as essential to a human rights approach. These gaps are not always filled by asylum and humanitarian mechanisms, so the following recommendations are made for policy changes.

\section{A The inadequacies of the current framework}

The current framework of New Zealand's response to trafficking is for the most part meeting the principles of a human rights approach. There remain, however, some gaps in New Zealand's policy that compromise the protection of victims. If a victim does not meet the requirements for a temporary or residence visa because he or she is not certified

224 Babulal v Chief Executive of Labour, above n 222, at [27]. 
as a victim, because he or she does not want to cooperate with the police, or does not meet the health requirements for a residence visa, the victim will need to rely on asylum mechanisms or a humanitarian appeal. If the victim cannot demonstrate a well-founded fear of persecution or a danger that he or she will suffer cruel treatment, the victim will be unsuccessful in a refugee or protection claim. Therefore, a victim of trafficking, who has already suffered the physical and psychological trauma of exploitation, and who would face hardship and isolation if he or she were to return to the home country, will face deportation unless he or she can successfully appeal the decision on humanitarian grounds. The problem with this approach, as discussed above, is that it leaves a victim without any certainty. To ameliorate these potential gaps in New Zealand's trafficking policy, two changes are recommended.

\section{B Victim status certification}

The first recommendation is that the certification of a person as a victim of trafficking should not depend on any law enforcement procedures. It is important that these two processes are separated. Of course, identification of a victim must lead to an investigation into trafficking offences, and where an offence is complained of, the victims should be identified. A victim should not, however, need to engage with the police to be recognised as a trafficking victim, and their certification should not depend on the ability to prosecute the perpetrators for trafficking.

One way to achieve this is to shift the authorisation procedure to a different agency, such as the Ministry of Social Development, which is primarily concerned with victim protection rather than criminal investigation. It may also be appropriate for nongovernmental organisations to facilitate the identification and authorisation of trafficking victims. If the agency in charge of this process is also involved in providing housing and other protection services, victims may be more likely to feel safe and take part in an interview. Additionally, determinations of a person's status as a victim of trafficking should be appealable, to minimise the risk that authorities fail to recognise victims.

\section{Amend residence visa requirements}

The second recommendation is to amend the requirements for a residence visa in two ways. First, to provide a waiver of health requirements, in the same way that these are waived for those with refugee or protected person status. This ensures that victims who are suffering from health conditions, which may even be a result of their trafficking experience, are not excluded from obtaining residence status. 
The second amendment to residence visas is to remove the requirement that victims not obstruct police investigations. The dangers of making immigration status an inducement for participating in investigations has already been explained: it compromises the aim of protecting victims, it can undermine the veracity of the victim, and it can discourage victims from coming forward. If victims choose not to engage with law enforcement due to their suspicion of government agencies and fear of deportation, it is not clear that they would do so to obtain a residence visa. Moreover, providing protection to victims irrespective of their decisions regarding involvement in police investigations is a foundational component of the human rights approach to trafficking. The model that Italy has adopted, which does not make residence contingent on assisting the police, could be considered in New Zealand. Amending the immigration instructions to reflect these changes would ensure that New Zealand is meeting the principles of unconditional protection, safe return and long-term residence for victims of trafficking.

\section{$V$ Conclusion}

Human trafficking is not a new spectacle. People have been treated as slaves and exploited for the profit of others for centuries. ${ }^{225}$ The volume of trafficking has, however, grown dramatically in recent years due to the increased movement of people across borders and the proliferation of organised crime. ${ }^{226}$ Recent experiences with labour exploitation in New Zealand demonstrate that it does not remain untouched by the scourge of trafficking. In the last fifteen years, the New Zealand government has recognised the need to respond to the "activities of criminal groups who seek to profit from human misery." 227

This paper has focused on New Zealand's immigration policy towards victims of trafficking, assessing it for compliance with the principles of a human rights approach. This emphasis recognises the role that immigration policies can play in the identification and protection of victims.

New Zealand's immigration policy towards trafficking victims was assessed in Part III for compliance with the above principles, and three gaps were identified. In cases where a person does not receive police certification of being a trafficking victim, where he or she chooses not to cooperate with the police, or where he or she does not meet the health

\footnotetext{
$225 \quad$ Ryszard Piotrowicz “The UNHCR's Guidelines on Human Trafficking” (2008) 20 Int'l J Refugee L 242 at 159.

226 Elizabeth Defeis, above n 67, at 486.

227 Hon Phil Goff (Minister of Justice), above n 6.
} 
requirements for a residence visa, the current immigration policy will not protect victims. The safeguard of refugee or protection status will not be available in all cases, and even so the asylum mechanisms do not meet all nine principles of a human rights approach. Similarly, the humanitarian grounds on which deportation can be challenged do not meet the standard of a human rights approach.

Due to the deficiencies in New Zealand's current framework, Part IV recommended two changes. The first is to shift the victim certification procedure to a different agency, to avoid the risk that certification will be contingent on cooperation with the police, and to introduce an appeal mechanism. The second is to include a waiver of health requirements for residence permits, and to remove the condition that victims do not obstruct police investigations. With these two amendments, New Zealand's immigration policy towards trafficking victims will meet the principles of a human rights approach.

Although the incidence of human trafficking in New Zealand is low, it is essential that there is an adequate framework in place. This means that when cases arise, they will be dealt with in a way that respects the fundamental rights of victims. 


\section{Bibliography}

\section{A Cases}

$1 \quad$ New Zealand

$A C$ (Egypt) [2011] NZIPT 800015.

AC (Russia) [2012] NZIPT 800151 at [87].

AC (Syria) [2011] NZIPT 800035 at [131].

Babulal v Chief Executive of Labour HC Auckland CIV-2011-404-1773, 29 September 2011.

BG (Fiji) [2012] NZIPT 800091.

Galanova v Minister of Immigration [2012] NZIPT 500426.

Refugee Appeal No 70074/96 Re ELLM Refugee Status Appeals Authority, 17 September 1996.

Refugee Appeal No 76044 Refugee Status Appeals Authority, 11 September 2008.

Ye v Minister of Immigration [2010] 1 NZLR 104 (SC).

2 United Kingdom

AZ (Trafficked women) Thailand CG [2010] UKUT 118.

\section{Canada}

Attorney-General v Ward [1993] 2 SCR 689.

Garcia v Minister of Citizenship and Immigration [2007] FCJ 118.

Talo v Minister of Citizenship and Immigration [2012] FCJ 478. 


\section{B Legislation}

4 New Zealand

Immigration Act 2009.

Immigration Act 1987.

\section{United States}

Trafficking Victims Protection Reauthorization Act Pub L No 109-164, title 1.

\section{European Union}

Council Directive 2004/81/EC on the residence permit issued to third-country nationals who are victims of trafficking in human beings or who have been the subject of an action to facilitate illegal immigration, who cooperate with the competent authorities [2004] OJ L261/19.

Directive 2011/36/EU of the European Parliament and of the Council on preventing and combating trafficking in human beings and protecting its victims, and replacing Council Framework Decision 2002/629/JHA [2011] OJ L101/1.

\section{Official Sources}

$7 \quad$ New Zealand

Department of Labour "Plan of Action to Prevent People Trafficking" (2009) $<$ www.dol.govt.nz $>$

Immigration New Zealand Operational Manual "Administration" (1 July 2013) $<$ http://www.immigration.govt.nz/migrant/general/generalinformation/operationalmanual $>$.

Immigration New Zealand Operational Manual "Residence" (1 July 2013) $<$ http://www.immigration.govt.nz/migrant/general/generalinformation/operationalmanual $>$.

Immigration New Zealand Operational Manual "Temporary entry" (1 July 2013) $<$ http://www.immigration.govt.nz/migrant/general/generalinformation/operationalmanual $>$. 
Ministry of Foreign Affairs and Trade "Protocol to Prevent, Suppress and Punish Trafficking of Persons, Especially Women and Children, Supplementing the United Nations Convention Against Transnational Organised Crime, National Interest Analysis" $<$ http://www.mfat.govt.nz>.

New Zealand Police "New Zealand Police Manual: People Trafficking and Migrant Smuggling" (Obtained under Official Information Act 1982 Request the New Zealand Police).

\section{Australia}

Anti-People Trafficking Interdepartmental Committee "Trafficking in Persons: The Australian Government Response 1 July 2011 - 30 June 2012" < http://www.ag.gov.au/>.

\section{Canada}

Citizenship and Immigration Canada "IP 1 Temporary Resident Permits” (19 June 2007)

\section{United States}

United States of America Department of State "Trafficking in Persons Report" (June 2013) US Department of State <www.state.gov>.

\section{European Union}

European Commission "Together against Trafficking in Human Beings: Italy" $<$ http://ec.europa.eu>.

Experts Group on Trafficking in Human Beings "Opinion on reflection period and residence permit” (18 May 2004) European Commission < http://ec.europa.eu/>.

\section{Books and Chapters in Books}

Anne T Gallagher The International Law of Human Trafficking (Cambridge University Press, Cambridge, 2010).

Guy S Goodwin-Gill The Refugee in International Law (2nd ed, Clarendon Press, Oxford, 1996).

Marjoleine Zieck UNHCR and Voluntary Repatriation of Refugees: A Legal Analysis (Kluwer Law International, The Hague, 1997). 


\section{E Journal Articles}

Stefano Caneppele and Marina Mancuso "Are Protection Policies for Human Trafficking Victims Effective? An Analysis of the Italian Case" (2013) 19 Eur J Crim Policy Res 259.

Seo-Young Cho and Krishna Chaitanya Vadlamannati "Compliance with the Antitrafficking Protocol” (2012) 28 Europ J Pol Econ 249.

Michele Anne Clark "Trafficking in Persons: an issue of human security" $4 \mathrm{~J}$ Hum Dev 247.

Gergana Danailova-Trainor and Frank Laczko "Trafficking in Persons and Development: Towards Greater Policy Coherence” (2010) 48 Int Migration 38.

Elizabeth Defeis "Protocol to Prevent, Suppress and Punish Trafficking in Persons - A New Approach” (2004) 10 ILSA J INT'L \& COMP L 485.

Timothy P Fadgen and Guy Charlton "Humanitarian Concerns and Deportation Orders under the Immigration Act 2009: Are International Obligations Enough Protection for the Immigrant with Mental Illness?” (2012) 43 Victoria U Wellington L Rev 423.

Joan Fitzpatric "Trafficking as a Human Rights Violation: The Complex Intersection of Legal Frameworks for Conceptualizing and Combating Trafficking” (2003) 24 Mich J Int'l L 1143.

Kalen Fredette "Revisiting the UN Protocol on Human Trafficking: Striking Balances for more Effective Legislation" (2009) 27 Cardozo J Int'1 \& Comp L 101.

Anne Gallagher "Human Rights and the New UN Protocols on Trafficking and Migrant Smuggling: A Preliminary Analysis” (2001) 23 Hum Rts Q 975.

Udara Jayasinghe and Sasha Baglay "Protecting Victims of Human Trafficking Within a 'Non-Refoulement' Framework: is Complementary Protection an Effective Alternative in Canada and Australia" [2011] 23 Int'1 J Refugee L 489.

Susan Kneebone "The Refugee-Trafficking Nexus: Making Good (The) Connections" (2010) 29 Refugee Survey Quarterly 137. 
Sharon Pickering "Transnational Crime and Refugee Protection" (2007) 34 Social Justice 47.

Ryszard Piotrowicz "The UNHCR's Guidelines on Human Trafficking” (2008) 20 Int'l J Refugee L 242.

LeRoy G Potts Jr "Global Trafficking in Human Beings: Assessing the Success to the United Nations Protocol to Prevent Trafficking in Persons" (2003) 35 Geo Wash Int'l L Rev 227.

April Rieger "Missing the Mark: Why the Trafficking Victims Protection Act Fails to Protect Sex Trafficking Victims in $\square$ the United States" (2007) 30 Harv J L \& Gender 231.

Hussein Sadruddin, Natalia Walter and Jose Hidalgo "Human Trafficking in the United States: Expanding Victim Protection Beyond Prosecution Witnesses" (2005) 16 Stan L \& Pol'y Rev 379.

Andreas Schloenhardt and Mark Loong "Return and Reintegration of Human Trafficking Victims from Australia" (2011) 27 Int J Refugee L 143.

Marie Segrave "Order at the border: The repatriation of victims of trafficking" (2009) 32 Women's Studies International Forum 251.

Susannah C Vance "An Enduring Fear: Recent Limitations on the Past Persecution Ground for Asylum” (2003) 91 Ky LJ 957.

Matilde Ventrella "Protecting Victims of Trafficking in Human Beings in the UK: The Italian 'Rimini Method' that Could Influence the British Approach" (2006) 3 J M R I 40.

Cathy Zimmerman et al "Stolen Smiles: The physical and psychological health consequences of women and adolescents trafficked into Europe" (2006) the London School of Hygiene and Tropical Medicine.

\section{F Speeches and Reports}

Susan Coppedge "People Trafficking: An International Crisis Fought at the Local Level" (prepared for the Ian Axford (New Zealand) Fellowships in Public Policy, July 2006).

Chris Frazer "Prevent People Trafficking Conference Report" (Wellington, 2013). 
Justice Susan Glazebrook "Human Trafficking in New Zealand" (Speech at 2010 International Association of Women Judges Conference, Seoul Korea, 14 May 2010).

Hon Phil Goff (Minister of Justice) Transnational Organised Crime Bill: Second Reading (30 May 2002).

Nathan Guy "Speech to the launch of STOP THE TRAFFICK Aotearoa New Zealand" (19 June 2012).

Christina Stringer, Glenn Simmons and Daren Coulston "Not in New Zealand's Waters, Surely? Labour and Human Rights Abuses Aboard Foreign Fishing Vessels” (2011) 11 New Zealand Asia Institute Working Paper Series 1.

Michael Woodhouse "Opening address to the Prevent People Trafficking Conference" (11 April 2013).

\section{G Letters}

Letter from B Perry (Detective Inspector, Acting National Manager New Zealand Police National Criminal Investigations Group) in response to request for information (23 September 2013).

\section{H Internet Sources}

Anti-Slavery International <http://www.antislavery.org $>$.

Neil Bickle, Department of Labour "Media Release 26 October 2010" $<$ www.dol.govt.nz $>$.

Dina Francesca Haynes "Used, Abused, Arrested and Deported: The Case for Extending Immigration Benefits to Protect Victims of Trafficking and Secure the Prosecution of Traffickers" (July 24, 2003) Bepress Legal Series Bepress Legal Series Working Paper 6 $<$ http://law.bepress.com/expresso/eps/6>.

Julie Middleton "UN expert warns NZ over human trafficking problem" (21 December 2005) New Zealand Herald <www.nzherald.co.nz>

"Contractor exploited migrant workers" Nelson Mail (online ed, Nelson, 31 January 2013). 
Isabella Orfano and Marco Bufo "The Italian system of assistance and integration of victims of trafficking in human beings" <http://ec.europa.eu/antitrafficking/download.action;jsessionid=d0C3S8GGqPSQvjRV186w0kcLyBn8Lvf7GqLB nyB3R5LP1fV8G2pp!444076514?nodePath=/National+Info+Pages/Italy/5.+RESOURCE $\mathrm{S} / 5.3+$ Reports/The + Italian + system + of + assistance + and + integration + of + victims + of + traffi cking + in + human + beings_en.pdf $\&$ fileName $=$ The + Italian + system + of + assistance + and + int egration + of + victims + of + trafficking + in + human + beings_en.pdf\&fileType $=$ pdf $>$.

UNESCO “Trafficking Statistics Project” (2011) < http://www.unescobkk.org>.

\section{International Materials}

\section{Treaties}

Convention for the Suppression of the Traffic in Persons and Exploitation of the Prostitution of Others 96 UNTS 271 (25 March 1950).

Convention on the Elimination of All Forms of Discrimination Against Women 1249 UNTS 13 (opened for signature 18 December 1979, entered into force 3 September 1981).

Convention Against Torture 1465 UNTS 85 (opened for signature 10 December 1984, entered into force 26 June 1987).

Convention on the Rights of the Child 1577 UNTS 3 (opened for signature 20 November 1989, entered into force 2 September 1990).

International Agreement for the Suppression of the "White Slave Trade," 1 LNTS 83 (18 May 1904).

International Agreement for the Suppression of the "White Slave Trade," 3 LNTS 278 (4 May 1910).

International Covenant on Civil and Political Rights 999 UNTS 171 (opened for signature 16 December 1966, entered into force 23 March 1976). 
Protocol to Prevent, Suppress and Punish Trafficking in Persons, Especially Women and Children (the Protocol) 2225 UNTS 209 (opened for signature 15 November 2000, entered into force 29 September 2003).

United Nations Convention Against Organised Transnational Crime 2237 UNTS 319 (opened for signature 15 November 2000, entered into force 25 December 2003).

United Nations Convention and Protocol on the Status of Refugees 189 UNTS 137 (opened for signature 28 July 1951, entered into force 22 April 1954).

\section{United Nations Materials}

Ad Hoc Committee on the Elaboration of a Convention against Transnational Organized Crime Draft Protocol to Combat International Trafficking in Women and Children Supplementary to the United Nations Convention on Transnational Organized Crime GA Res 254/4 A/AC.254/4/Add.3 (1998).

Ad-Hoc Committee on the Elaboration of a Convention Against Transnational Organised Crime, Note by the United Nations High Commissioner for Human Rights, the United Nations Children's Fund, the United Nations High Commissioner for Refugees, and the International Organisation for Migration on the draft protocols concerning migrant smuggling and trafficking in persons GA Res 254 A/AC.254/27 (1999).

United Nations High Commissioner for Human Rights Informal Note: Ad Hoc Committee on the Elaboration of a Convention against Transnational Organized Crime GA Res 254 A/AC.254/16 (1999).

Office of the High Commissioner or Human Rights CCPR General Comment 20 (1992) XLIV.

\section{United Nations Publications}

Basic Principles and Guidelines on the Right to a Remedy and Reparation for Victims of Gross Violations of International Human Rights Law and Serious Violations of International Humanitarian Law GA Res 60 A/RES/60/147 (2006).

United Nations Office of the High Commissioner for Human Rights Recommended Principles and Guidelines on Human Rights and Human Trafficking Commentary (United Nations, New York and Geneva, 2010). 
Training Manual for Combating trafficking in Women and Children, developed as part of the United Nations Inter-agency Project on Trafficking in Women and Children in the Sub-Mekong Region $<$ http://www.un.or.th/traffickingProject/trafficking_manual.pdf $>$.

International Organisation for Migration "Consequences of Re-trafficking: Evidence from the IOM Human Trafficking Database" (2010).

United Nations Office on Drugs and Crime Division for Treaty Affairs Legislative Guides for the Implementation of the United Nations Convention Against Transnational Organized Crime and The Protocols Thereto (Legislative Guides) (United Nations, New York, 2004).

United Nations Office on Drugs and Crime Travaux Préparatories of the Negotiations for the Elaboration of the United Nations Convention against Organized Transnational Crime and the Protocols Thereto (Travaux Préparatories) (United Nations, New York, 2006).

James Oatway Human Trafficking: Joint UN Commentary on the EU Directive - A Human Rights-Based Approach (UNHCR, 2011).

IOM Handbook on Direct Assistance for Victims of Trafficking $<$ www.iom.int/jahia/webdav/site/myjahiasite/shared/shared/mainsite/published_docs/boo ks/CT\%20handbook.pdf $>$.

United Nations Secretary-General "Improving the coordination of efforts against trafficking in persons Background paper" $<$ https://www.un.org/ga/president/63/letters/SGbackgroundpaper.pdf $>$.

UNHCR "Guidelines on International Protection: The Application of Article 1A(2) of the 1951 Convention and/or 1967 Protocol relating to the Status of Refugees to victims of trafficking and persons at risk of being trafficked" (2007) 19 Int'1 J Refugee L 372. 